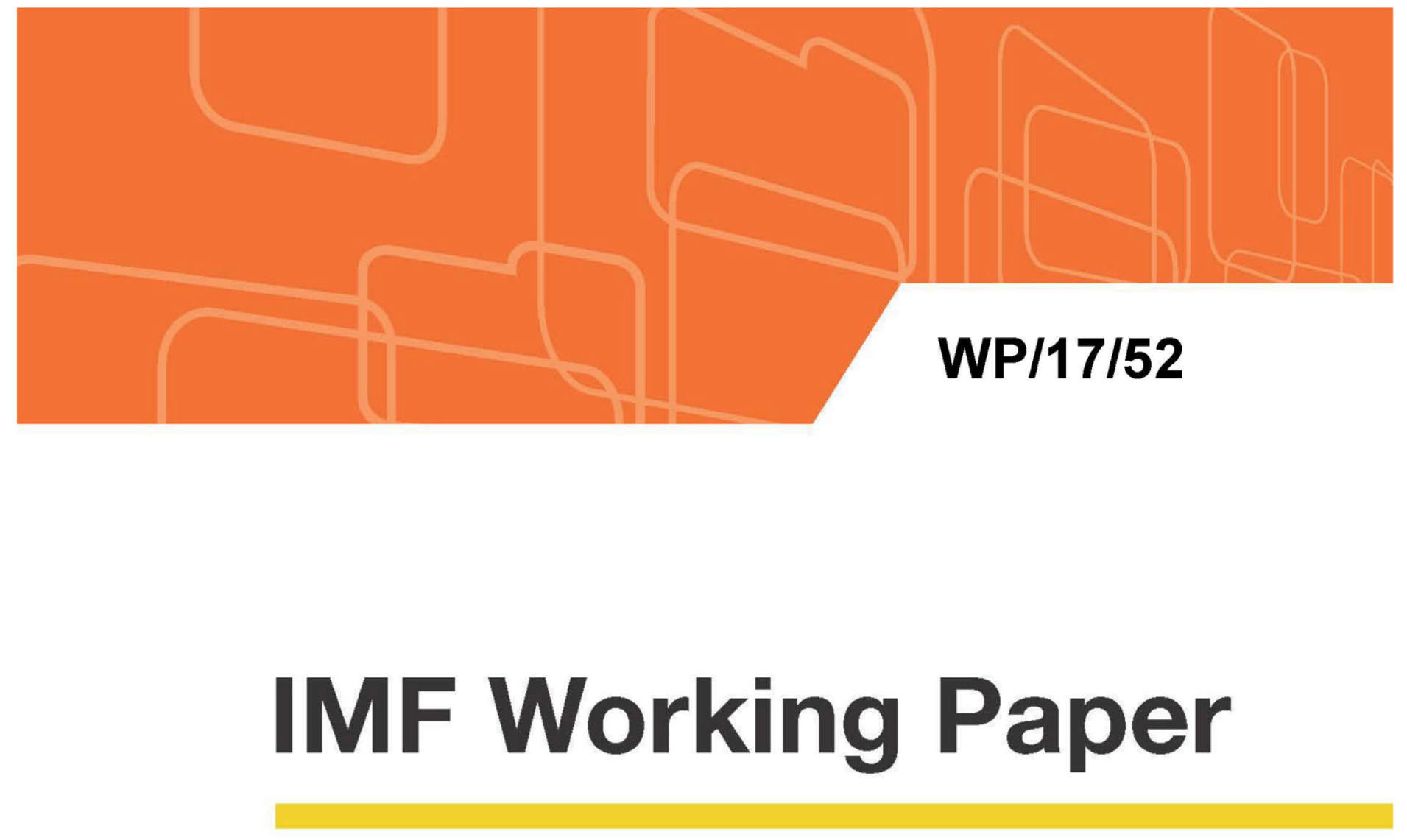

\title{
The Drivers of Capital Flows in Emerging Markets Post Global Financial Crisis
}

by Swarnali Ahmed Hannan

IMF Working Papers describe research in progress by the author(s) and are published to elicit comments and to encourage debate. The views expressed in IMF Working Papers are those of the author(s) and do not necessarily represent the views of the IMF, its Executive Board, or IMF management.

$$
\text { I N T E R N A T I O N A L M O N E T A R Y F U N D }
$$




\title{
WP/17/52
}

\section{IMF Working Paper}

\section{The Drivers of Capital Flows in Emerging Markets Post Global Financial Crisis}

\author{
by Swarnali Ahmed Hannan
}

IMF Working Papers describe research in progress by the author(s) and are published to elicit comments and to encourage debate. The views expressed in IMF Working Papers are those of the author(s) and do not necessarily represent the views of the IMF, its Executive Board, or IMF management.

$$
\text { I N T ER N A T I O N A L M O N E T A R Y F U N D }
$$




\title{
IMF Working Paper
}

Strategy, Policy and Review Department

\section{The Drivers of Capital Flows in Emerging Markets Post Global Financial Crisis Prepared by Swarnali Ahmed Hannan}

Authorized for distribution by Martin Kaufman

February 2017

\section{IMF Working Papers describe research in progress by the author(s) and are published to elicit comments and to encourage debate. The views expressed in IMF Working Papers are those of the author(s) and do not necessarily represent the views of the IMF, its Executive Board, or IMF management.}

\begin{abstract}
Using a sample of 34 emerging markets and developing economies over the period 2009Q32015Q4, the paper employs a panel framework to study the determinants of capital flows, both net and gross, across a wide range of instruments. The baseline regressions are then extended to focus on high and low episodes - quarters with flows one standard deviation above/below mean. Overall, the results suggest that the capital flow slowdown witnessed in recent years is due to a combination of lower growth prospects of recipient countries and worse global risk sentiment. However, the determinants of flows can be considerably different across instruments and across the type of flows considered, net or gross. The sensitivity of certain types of flows, towards push and pull factors, increases during periods of high and low capital flows. Moreover, some variables may not necessarily be significant during normal times, but can be important drivers during such episodes, and vice versa. Indicators like the gap between the U.S. long- and short-term maturity bond yields - not significant during normal times - can be an important driver during high episodes.
\end{abstract}

JEL Classification Numbers: F3

Keywords: capital flows, emerging market economies

Author's E-Mail Address: sahmed@imf.org 


\section{Contents}

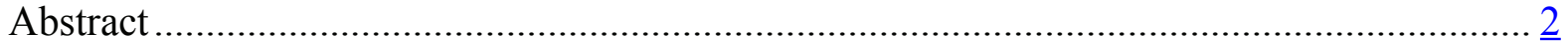

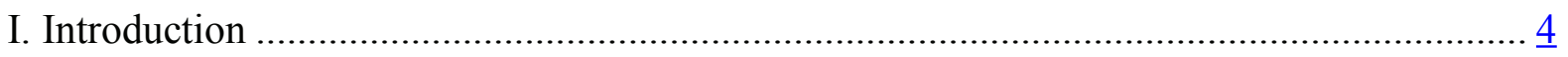

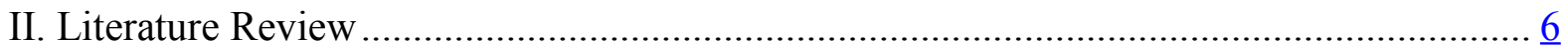

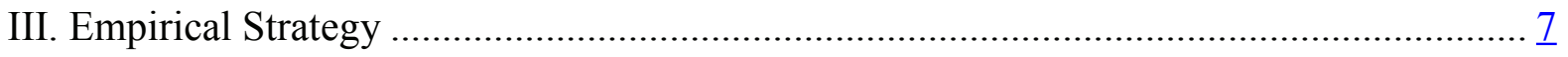

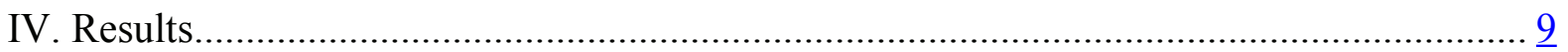

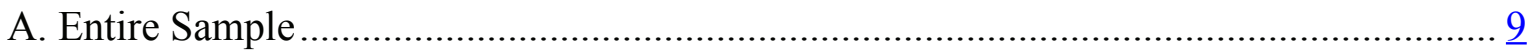

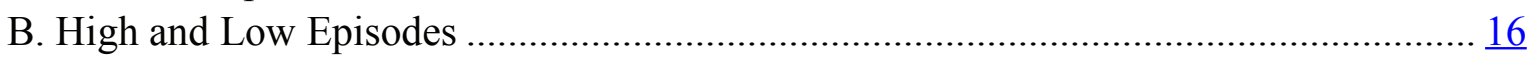

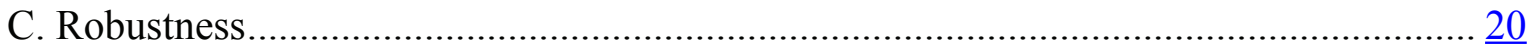

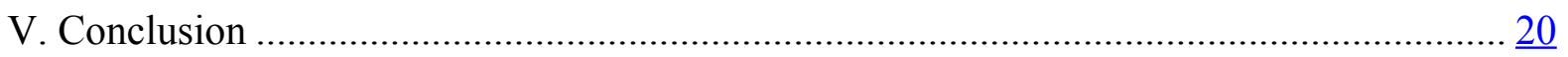

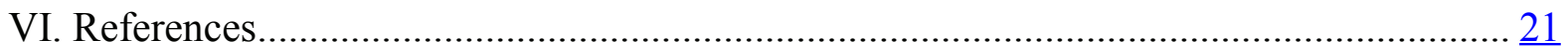

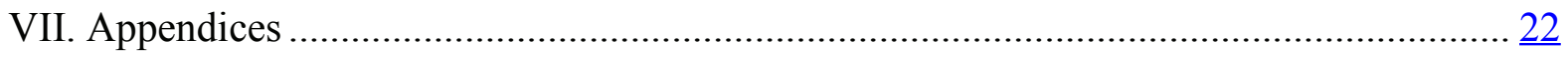

A. Appendix I - List of Countries ………………………………………………… 22

B. Appendix II - Data Sources ………………………………………………………

C. Appendix III - Results of High/Low Episodes ………………………………….... 23

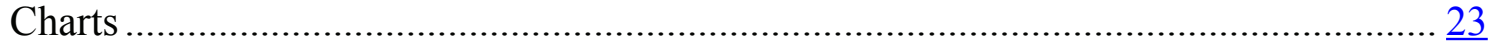

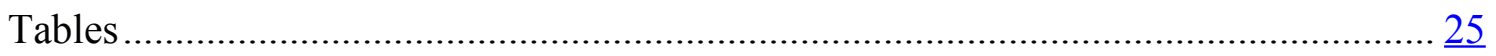




\section{INTRODUCTION ${ }^{1}$}

A lot has changed in the capital flows world since the global financial crisis. While the pre-crisis era was marked by gradual (and for some sharp) rise in capital flows owing to increasing financial integration and strong growth prospects in the emerging markets, capital flows tanked during the Global Financial Crisis (GFC) and, after a surge post crisis, have been subject to volatility since then (Ahmed and Zlate, 2014). In particular, recent literature has focused on the slowdown in capital flows witnessed since 2010 and the underlying reasons (IMF 2016a). While FDI still dominates total flows, portfolio and other investment flows have also increased over time, giving policy makers new challenges about how to deal with the higher volatility associated with such flows (Pagliari and Hannan, forthcoming). In earlier literature, the focus was on net flows, but recent literature has stressed the need to study gross inflows and outflows as well since the results can be substantially different (Forbes and Warnock, 2012). Overall, using Ahmed and Zlate's (2014) title, it is indeed a "brave new world" for capital flows, where nuances matter.

This paper provides a comprehensive picture of the drivers of recent capital flows. The analysis draws from recent literature on the determinants of capital flows. In particular, the study builds upon the work done by IMF (2016a), and extends the analysis in few key dimensions. First, the time period under consideration is more recent, starting from 2009 Q3. This helps to understand the key drivers of capital flows since the GFC. Second, the analysis encompasses not only the overall total flows but also the key instruments. Though Ahmed and Zlate (2014) have focused on recent time period, the analysis in this paper covers a wider range of instruments. Third, in line with the suggestions of Forbes and Warnock (2012), it includes both net and inflows/outflows. Finally, the baseline regressions are extended to examine the determinants of high and low capital flow movements since mid-2009. The analysis focuses on the determinants of capital flows during high and low episodes where high episodes are defined as quarters where flows are one standard deviation above mean, and vice versa for low episodes. While other studies have looked at longer samples, focusing

\footnotetext{
${ }^{1}$ I would like to thank Mohammed Saleh for his excellent research assistance. In addition, I am grateful to Vivek Arora, Luis Catao, Paolo Cavallino, Varapat Chensavasdijai, Luis Jacome, Martin Kaufman, Zsoka Koczan, Maria Sole Pagliari, Tjoervi Olafsson, and Mahvash Qureshi for their helpful suggestions and comments. All remaining errors are mine.
} 
on high and low capital flow movements since mid-2009 helps to understand if the drivers have changed in recent times.

Using a sample of thirty-four emerging markets and developing economies (EMDEs) over the period 2009Q3-2015Q4, the paper employs a panel framework to study the determinants of capital flows, both net and gross flows, across a wide range of instruments, comprising private, FDI, portfolio, portfolio debt, portfolio equity, and other investment flows. The time period is chosen such that the post-crisis capital flow determinants can be captured in the analysis, with the start date corresponding to the quarter by which flows had recovered from the crisis (Ahmed and Zlate, 2014). The dependent variables comprise the generally used push and pull factors considered in literature.

In line with the recent literature, the results suggest that capital flows are driven by a confluence of factors, including growth differentials, interest rate differentials, global risk aversion, trade openness, reserves, institutional quality, and financial development. In other words, both push and pull factors are important determinants. However, there is considerable variation across instruments and also the types of flows considered (net or gross). For example, growth differential matters for non-residents' portfolio investment, while the search for yield influences residents' choice to invest abroad. On the other hand, for other investment flows, interest rate differential influences both residents' decision to invest abroad as well as nonresidents' decision to invest in the recipient economy.

The results on high and low episodes indicate that some types of flows can be more sensitive towards push and pull factors during such episodes. As with the baseline, there is variation across instruments and types of flows considered (net or gross). Interestingly, the results indicate that the sensitivity towards the U.S. yield gap ${ }^{2}$ increases during high episodes. However, the U.S. yield gap is not statistically significant during the baseline case. This indicates that the drivers of capital flows can be different during normal times and high and low episodes.

There are three main policy messages from this paper. First, the determinants of capital flows can be considerably different across instruments and across the type of flows

\footnotetext{
2 The gap between the long- and short-maturity government bond yields in the United States. 10-year and 3-year bond yields are used.
} 
considered, net or gross. Second, both push and pull factors matter for normal times as well as surges and busts. Third, the determinants of flows can be different during normal times versus surges and busts. Indicators like the U.S. yield gap - not significant during normal times - can be an important driver during high episodes.

One caveat to this exercise is worth mentioning. The results are influenced by the fact that the period considered is after the global financial crisis. Hence, some of the coefficients might be influenced by the specific time frame considered in the paper and may not be necessarily representative of what should be the relationship from a longer time perspective, both in terms of theoretical predictions as well as empirical analysis with longer time frames.

The rest of the paper is organized as follows. Section II gives a brief review of literature. Section III discusses the empirical strategy. Section IV presents the results, both for the baseline case and high/low episodes. Finally, Section V concludes.

\section{Literature ReVIEW}

Literature on the determinants of capital flows is based using the tenets of portfolio theory in which expected returns, risk, and risk preferences matter (Ahmed and Zlate, 2014). The determinants are usually divided into external 'push' factors and domestic 'pull' factors. The push factors refer to external conditions that attract investors to increase exposure in a particular country, while the pull factors are the domestic country characteristics that affect risks and returns to investors.

Using this general idea, the analysis on the determinants of capital flows can be, broadly speaking, grouped into two strands. As discussed in Ahmed (2015), the first strand of work focuses on the extreme capital flow episodes - sudden stops and surges - to understand the key determinants of capital flows (Calvo, 1998; Forbes and Warnock, 2012). One of the key insights from this strand of literature is that push factors seem to influence whether inflow surges occur and the riskiness of flows, while pull factors determine the direction and magnitude of such surges (Ghosh, Qureshi, Kim and Zalduendo, 2014). The second strand of literature, comprising relatively more recent work, focuses on the entire sample, rather than extreme episodes, with the idea that it is difficult to identify how the longer-term determinants of capital flows may have changed over time when considering only surges and stops (IMF, 2016a; Ahmed and Zlate, 2014; IMF 2011a; IMF 2011b). 
Both strands of literature show that both push and pull factors are important for capital flows (IMF, 2016b). Push factors seem to influence whether inflow surges occur and the riskiness of flows, while pull factors determine the direction and magnitude of surges (Ghosh et al., 2014). IMF (2016a) shows that growth differentials, global risk aversion, and interest rate differentials remain key drivers of capital flows. Ahmed and Zlate (2014), Nier et al. (2014), and Koepke (2015) derive similar conclusions.

Recent studies have emphasized the importance of distinguishing between gross and net flows (Ghosh, Qureshi, Kim and Zalduendo, 2014; Forbes and Warnock, 2012; Broner, Didier, Erce and Schmukler, 2013). Forbes and Warnock (2012) argue that it is important to disaggregate capital flows by foreign and domestic investors since they can respond to shocks in a different manner, owing to factors such as different exposures to the domestic exchange rate or different degrees of access to liquidity. In some cases, their responses could partially counterbalance each other, leading to greater stability in net flows. In other cases, their actions could magnify each other, increasing the instability of net flows. Pagliari and Hannan (forthcoming) find similar results.

\section{EMPIRICAL STRATEgY}

Following the literature, the determinants of capital flows are grouped into "push" and "pull" factors. The starting point is a general empirical model that is often used to analyze the determinants of capital flows:

$$
y_{i, t}=\alpha_{0}+\sum_{i=1}^{n-1} \alpha_{i} D_{i}+\beta_{0} \text { External }_{t}+\beta_{1} \text { Domestic }_{i, t}+\varepsilon_{i, t}
$$

The left hand-side, $y_{i, t}$, represents the ratio of flows - either total or key instruments to country $i$ during time period $t$, as a fraction of the country's nominal GDP. ${ }^{3}$ The flows as a share of GDP are modeled as a function of fixed effects $\left(D_{i}=1\right.$ if an observation pertains to country $i, 0$ otherwise), a vector of variables representing external conditions or push factors, a vector of variables representing domestic or pull factors. Net inflows, gross inflows and

\footnotetext{
${ }^{3}$ Consistent with Financial Flows Analytics (FFA) database, net capital flows are always shown as net inflows, defined as gross inflows (change in domestic resident liabilities to foreigners) minus gross outflows (change in foreign assets owned by domestic residents).
} 
gross outflows are all considered as separate dependent variables for both total and private flows, and a wide range of instruments comprising FDI, portfolio, portfolio debt, portfolio equity and other investment flows. Table 1 gives details of the independent variables. They include the generally used push and pull factors considered in literature, with the pull factors including structural variables as well as factors that are differentials vis-à-vis the US (the interest rate and growth differentials). The push factors consist of global risk aversion, commodity prices, global liquidity, U.S. corporate spreads and U.S. yield gap. The last two variables, also used in IMF (2016a), capture additional global factors that may likely influence capital flow movements.

\section{Table 1: Determinants of Capital Flows}
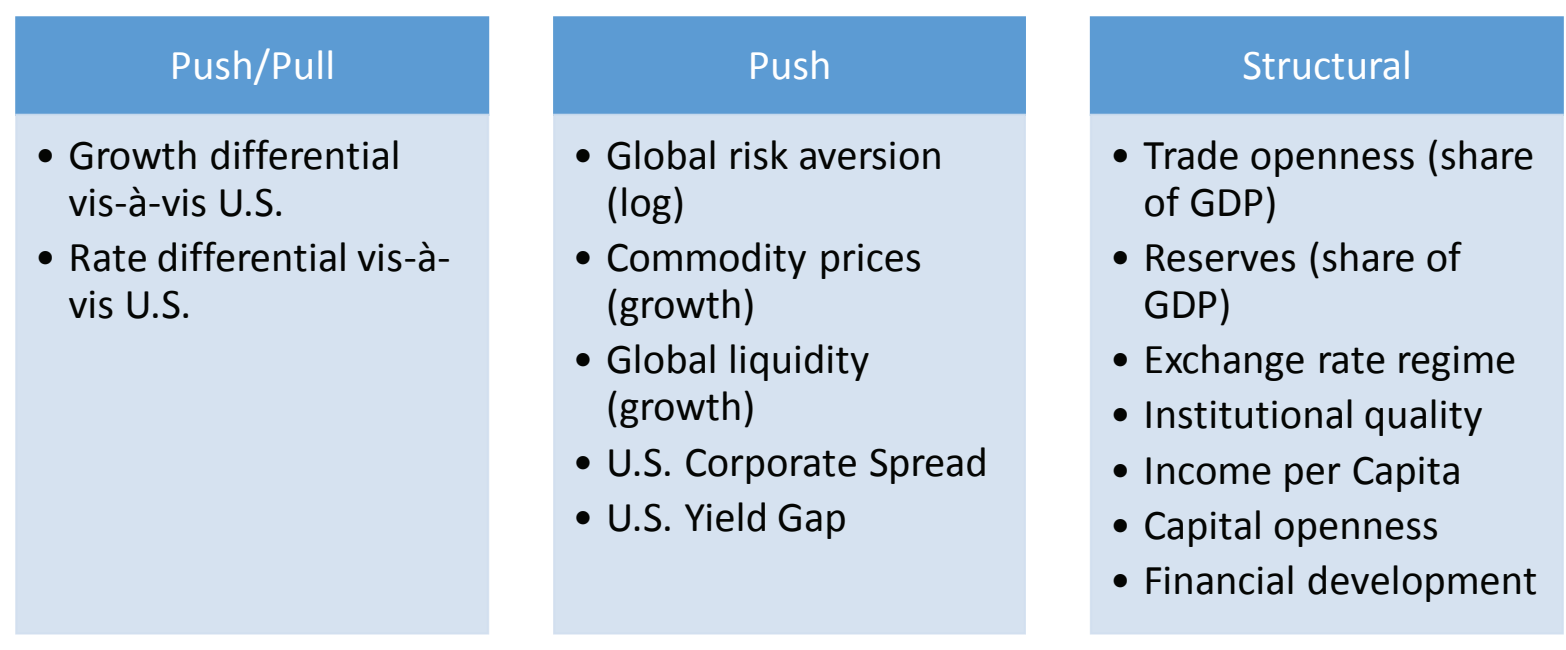

The regression analysis is performed using a panel framework comprising thirty-four EMDEs (listed in Appendix I) with country fixed effects. Driscoll-Kraay standard errors are used for estimated coefficients to control for potential serial correlation and cross-section dependence. The time period is 2009Q3-2015Q4 (quarterly data). The time period is chosen such that the post-crisis capital flow determinants can be captured in the analysis, with the start date corresponding to the quarter by which flows had recovered from the crisis (Ahmed and Zlate, 2014). The start date also corresponds to the first quarter after the U.S. business cycle trough as identified by National Bureau of Economic Research (NBER, http://www.nber.org/cycles.html). The sources of data used for the analysis is given in Appendix II. 
When analyzing the determinants of extreme capital flows episodes, the literature usually identifies the episodes by restricting the sample by some criteria. In order to determine the drivers of capital flows during high and low capital flow movements, the baseline analysis is extended. The same empirical strategy is used. However, the sample is restricted only to quarters where capital flows are one standard deviation above or lower than mean. The standard deviation and mean are computed using the entire sample, 2009Q32015Q4. High episodes are quarters where capital flows are at least one standard deviation above mean, whereas low episodes are quarters where flows are at least one standard deviation lower than mean.

\section{Results}

This section consists of three parts. In the first part, the results using the entire sample are discussed. The second part looks at the results when episodes with high and low capital flows are used. Finally, the last part discusses the robustness of the main findings. Before discussing the results, one caveat is warranted. The results are influenced by the fact that the period considered is after the global financial crisis. As such, some of the coefficients might be influenced by the specific time frame considered in the paper and may not be necessarily representative of what should be the relationship from a longer time perspective, both in terms of theoretical predictions as well as empirical analysis with longer time frames. Future research could look into some of these issues in depth to understand the puzzles.

\section{A. Entire Sample}

Tables 2, 3 and 4 report the baseline results for net and gross inflows/outflows, showing the determinants for total flows and key components like private, FDI, portfolio, portfolio debt, portfolio equity, and other investment.

Push/pull factors: The results indicate that cyclical factors like growth and interest rate differentials are statistically significant for flows. However, there are some differences across instruments and types of flows considered (net, gross inflows/outflows). The model predicts that a one percentage point increase in real GDP growth differential vis-à-vis the U.S. would increase net total flows by 0.25 percent of GDP, while a one percentage point increase in 
interest rate differential vis-à-vis the U.S. would increase net total flows by 0.51 percent of GDP. Growth and interest rate differentials are not statistically significant for net FDI flows, but matter for net portfolio and net other investment flows.

The results for gross total capital inflows and gross FDI inflows are similar to that of net flows. Growth differentials are statistically significant for gross portfolio inflows, while interest rate differentials matter for gross portfolio outflows. This indicates that growth differential matters for non-residents' portfolio investment, while the search for yield probably influences residents' choice to invest abroad. On the other hand, interest rate differential is statistically significant for other investment flows, both gross inflows and gross outflows.

Structural factors: A host of slow-moving structural factors are responsible for capital flows, including trade openness, reserves, institutional quality, income per capita, capital account openness, and financial development. However, as in the case of growth and interest rate differentials, there are differences in terms of instruments as well as net versus gross flows. Trade openness is important for net FDI and net portfolio flows, with a one percentage point increase in trade openness increasing net FDI flows by 0.03 percent of GDP. The response of net FDI flows towards trade openness is mainly due to the increase in gross FDI inflows (statistically significant) rather than gross FDI outflows (statistically insignificant). Financial development matters for net FDI and net portfolio debt. The caveat presented at the beginning of the section holds particularly for the results of capital account openness, which shows that the variable is statistically significant for some instruments for gross capital outflows, not significant for gross inflows, and significant for net FDI and net portfolio equity flows but with a negative sign. The results are influenced by the period considered and is not a representative of the expected relationship between flows and capital account openness. Moreover, since indicators like capital account openness are slow moving variables, their impact might not be accurately captured in such short samples. Future work could delve into this issue further.

Push factors: Push factors like global risk aversion, U.S. yield gap, U.S. corporate spread, and commodity prices seem to affect various components of capital flows. Global risk 
aversion is one of the key global factors that is statistically significant for net private flows and net portfolio debt flows. While not statistically significant for net flows, both gross inflows and gross outflows of FDI are sensitive to global risk aversion - more global risk aversion leads to higher inflows and higher outflows. Global commodity prices are also statistically significant.

Table 2:

Net Capital Flows (Share of GDP)

\begin{tabular}{|c|c|c|c|c|c|c|c|}
\hline \multirow[b]{3}{*}{ VARIABLES } & $(1)$ & $(2)$ & (3) & (4) & (5) & (6) & (7) \\
\hline & \multicolumn{7}{|c|}{ 2009Q3-2015Q4 } \\
\hline & Total & Private & FDI & Portfolio & $\begin{array}{c}\text { Portfolio } \\
\text { Debt }\end{array}$ & $\begin{array}{l}\text { Porfolio } \\
\text { Equity }\end{array}$ & Other \\
\hline \multirow[t]{2}{*}{ Growth differential } & $0.25 * * *$ & $0.38 * * *$ & 0.05 & $0.06^{*}$ & 0.05 & 0.03 & $0.13^{*}$ \\
\hline & $(0.08)$ & $(0.11)$ & $(0.04)$ & $(0.03)$ & $(0.04)$ & $(0.02)$ & $(0.07)$ \\
\hline \multirow[t]{2}{*}{ Interest rate differential } & $0.51 * * *$ & 0.13 & 0.02 & $0.12 * *$ & 0.04 & $0.12 * *$ & $0.40 * * *$ \\
\hline & $(0.13)$ & $(0.18)$ & $(0.04)$ & $(0.06)$ & $(0.06)$ & $(0.04)$ & $(0.11)$ \\
\hline \multirow[t]{2}{*}{ Trade openness } & $-0.07 * *$ & -0.03 & $0.03 * * *$ & $-0.05 * * *$ & $-0.04 * *$ & -0.01 & -0.05 \\
\hline & $(0.03)$ & $(0.03)$ & $(0.01)$ & $(0.02)$ & $(0.02)$ & $(0.01)$ & $(0.03)$ \\
\hline \multirow[t]{2}{*}{ Reserves } & $0.06 * * *$ & $0.06 * *$ & 0.00 & $0.05^{* * *}$ & $0.03 * * *$ & 0.01 & 0.01 \\
\hline & $(0.02)$ & $(0.03)$ & $(0.00)$ & $(0.01)$ & $(0.01)$ & $(0.00)$ & $(0.02)$ \\
\hline \multirow[t]{2}{*}{ ER Regime } & 0.09 & -0.09 & 0.02 & -0.37 & -0.27 & -0.17 & 0.49 \\
\hline & $(0.40)$ & $(0.54)$ & $(0.12)$ & $(0.39)$ & $(0.30)$ & $(0.14)$ & $(0.35)$ \\
\hline \multirow[t]{2}{*}{ Institutional Quality } & -0.77 & 2.60 & -1.61 & -1.14 & -3.08 & $1.70 * * *$ & 1.82 \\
\hline & $(2.60)$ & (3.29) & $(1.00)$ & $(2.22)$ & $(2.58)$ & $(0.42)$ & $(2.16)$ \\
\hline \multirow[t]{2}{*}{ Income per capita } & $0.00 * *$ & 0.00 & 0.00 & 0.00 & 0.00 & 0.00 & $0.00 *$ \\
\hline & $(0.00)$ & $(0.00)$ & $(0.00)$ & $(0.00)$ & $(0.00)$ & $(0.00)$ & $(0.00)$ \\
\hline \multirow[t]{2}{*}{ Capital account openness } & -3.37 & -3.25 & $-1.67 * *$ & -1.02 & 0.81 & $-1.18 * * *$ & -0.59 \\
\hline & $(2.58)$ & (3.07) & $(0.75)$ & $(2.47)$ & $(1.74)$ & $(0.33)$ & $(1.15)$ \\
\hline \multirow[t]{2}{*}{ Financial Development } & -18.70 & -20.45 & $11.43^{* *}$ & 2.88 & $17.78 *$ & $-11.85 * * *$ & $-33.55^{* *}$ \\
\hline & $(18.83)$ & $(20.18)$ & $(4.65)$ & $(8.97)$ & $(8.64)$ & $(4.10)$ & (14.99) \\
\hline \multirow[t]{2}{*}{ Global risk aversion (log) } & -2.38 & $-4.81 * * *$ & 0.04 & $-1.70 * * *$ & $-1.25^{* *}$ & -0.36 & -0.61 \\
\hline & $(1.65)$ & $(1.65)$ & $(0.29)$ & $(0.52)$ & $(0.46)$ & $(0.25)$ & $(1.16)$ \\
\hline \multirow[t]{2}{*}{ Commodity prices (growth) } & -0.01 & $0.04 * *$ & -0.00 & $0.02 * *$ & $0.02 * *$ & $0.00 * *$ & -0.03 \\
\hline & $(0.03)$ & $(0.02)$ & $(0.00)$ & $(0.01)$ & $(0.01)$ & $(0.00)$ & $(0.03)$ \\
\hline \multirow[t]{2}{*}{ Global liquidity (growth) } & 0.06 & 0.02 & -0.02 & 0.08 & 0.07 & -0.01 & -0.01 \\
\hline & $(0.11)$ & $(0.10)$ & $(0.02)$ & $(0.05)$ & $(0.05)$ & $(0.02)$ & $(0.07)$ \\
\hline \multirow[t]{2}{*}{ U.S. Corporate Spread } & $2.17 * *$ & $3.18 * * *$ & $0.37 *$ & $0.95 * *$ & 0.25 & $0.45 * *$ & 0.70 \\
\hline & $(0.80)$ & $(1.11)$ & $(0.21)$ & $(0.42)$ & $(0.38)$ & $(0.20)$ & $(0.74)$ \\
\hline \multirow[t]{2}{*}{ U.S. Yield Gap } & 1.01 & -0.86 & $0.31 * *$ & -0.82 & $-0.91 *$ & -0.02 & 1.45 \\
\hline & $(1.86)$ & $(1.26)$ & $(0.14)$ & $(0.58)$ & $(0.50)$ & $(0.12)$ & $(1.38)$ \\
\hline \multirow[t]{2}{*}{ Constant } & 0.24 & 8.83 & $-5.84 * *$ & 2.41 & -2.67 & $3.37 *$ & 3.58 \\
\hline & $(13.10)$ & $(11.82)$ & $(2.35)$ & $(4.53)$ & $(4.87)$ & $(1.83)$ & $(11.36)$ \\
\hline Observations & 809 & 809 & 809 & 809 & 778 & 770 & 809 \\
\hline Number of groups & 34 & 34 & 34 & 34 & 34 & 34 & 34 \\
\hline Country Fixed Effects & YES & YES & YES & YES & YES & YES & YES \\
\hline
\end{tabular}

Standard errors in parentheses

$* * * p<0.01, * * p<0.05, * p<0.1$ 
Table 3:

Capital Inflows (Share of GDP)

\begin{tabular}{|c|c|c|c|c|c|c|c|}
\hline \multirow[b]{3}{*}{ VARIABLES } & \multirow[t]{2}{*}{ (1) } & \multirow[t]{2}{*}{$(2)$} & (3) & (4) & \multirow[t]{2}{*}{ (5) } & \multirow[t]{2}{*}{ (6) } & \multirow[t]{2}{*}{ (7) } \\
\hline & & & \multicolumn{2}{|c|}{ 2009Q3-2015Q4 } & & & \\
\hline & Total & Private & FDI & Portfolio & $\begin{array}{c}\text { Portfolio } \\
\text { Debt }\end{array}$ & $\begin{array}{c}\text { Porfolio } \\
\text { Equity }\end{array}$ & Other \\
\hline \multirow[t]{2}{*}{ Growth differential } & $0.21 *$ & $0.32 * *$ & 0.07 & $0.06 *$ & $0.07 *$ & 0.01 & 0.07 \\
\hline & $(0.12)$ & $(0.12)$ & $(0.05)$ & $(0.03)$ & $(0.04)$ & $(0.01)$ & $(0.09)$ \\
\hline \multirow[t]{2}{*}{ Interest rate differential } & $0.31 *$ & -0.14 & 0.10 & 0.04 & 0.05 & 0.02 & $0.22 *$ \\
\hline & $(0.16)$ & $(0.16)$ & $(0.09)$ & $(0.05)$ & $(0.06)$ & $(0.01)$ & $(0.12)$ \\
\hline \multirow[t]{2}{*}{ Trade openness } & -0.01 & 0.05 & $0.06^{*}$ & -0.03 & $-0.03 * *$ & $-0.01^{*}$ & -0.02 \\
\hline & $(0.05)$ & $(0.05)$ & $(0.03)$ & $(0.02)$ & $(0.02)$ & $(0.00)$ & $(0.04)$ \\
\hline \multirow[t]{2}{*}{ Reserves } & $0.06 * *$ & $0.07 * *$ & $0.03 *$ & $0.04 * *$ & $0.04 * *$ & $0.00 * *$ & -0.00 \\
\hline & $(0.02)$ & $(0.03)$ & $(0.01)$ & $(0.01)$ & $(0.02)$ & $(0.00)$ & $(0.03)$ \\
\hline \multirow[t]{2}{*}{ ER Regime } & 0.26 & -0.24 & -0.03 & -0.29 & -0.27 & -0.09 & 0.61 \\
\hline & $(0.45)$ & $(0.37)$ & $(0.11)$ & $(0.32)$ & $(0.30)$ & $(0.05)$ & $(0.42)$ \\
\hline \multirow[t]{2}{*}{ Institutional Quality } & $-8.85^{* * *}$ & $-6.90 *$ & -2.41 & -1.79 & -1.58 & -0.30 & $-4.69 *$ \\
\hline & $(2.68)$ & $(3.37)$ & $(1.80)$ & $(2.08)$ & $(2.32)$ & $(0.32)$ & $(2.66)$ \\
\hline \multirow[t]{2}{*}{ Income per capita } & $0.00 * *$ & $0.00 * * *$ & $0.00 *$ & -0.00 & 0.00 & -0.00 & $0.00 * *$ \\
\hline & $(0.00)$ & $(0.00)$ & $(0.00)$ & $(0.00)$ & $(0.00)$ & $(0.00)$ & $(0.00)$ \\
\hline \multirow[t]{2}{*}{ Capital account openness } & -2.17 & -1.95 & -1.35 & 0.38 & 1.54 & -0.14 & -1.34 \\
\hline & $(2.38)$ & $(2.74)$ & $(1.00)$ & $(2.27)$ & (1.59) & $(0.22)$ & $(1.46)$ \\
\hline \multirow[t]{2}{*}{ Financial Development } & -19.12 & -27.60 & -10.31 & 1.30 & 6.91 & -2.55 & -6.89 \\
\hline & $(24.24)$ & $(25.69)$ & $(21.68)$ & $(9.40)$ & (8.79) & $(1.75)$ & $(9.56)$ \\
\hline \multirow[t]{2}{*}{ Global risk aversion (log) } & -0.56 & -3.02 & $1.96 * *$ & $-2.41 * *$ & $-1.94 * *$ & -0.35 & 0.08 \\
\hline & $(2.72)$ & $(2.23)$ & $(0.81)$ & $(1.17)$ & $(0.80)$ & $(0.26)$ & $(1.44)$ \\
\hline \multirow[t]{2}{*}{ Commodity prices (growth) } & -0.04 & -0.00 & $-0.02 * *$ & 0.01 & 0.01 & -0.00 & -0.03 \\
\hline & $(0.04)$ & $(0.02)$ & $(0.01)$ & $(0.01)$ & $(0.01)$ & $(0.00)$ & $(0.02)$ \\
\hline \multirow[t]{2}{*}{ Global liquidity (growth) } & 0.10 & 0.07 & $0.08 *$ & 0.08 & 0.06 & -0.00 & -0.06 \\
\hline & $(0.13)$ & $(0.11)$ & $(0.04)$ & $(0.07)$ & $(0.06)$ & $(0.01)$ & $(0.07)$ \\
\hline \multirow[t]{2}{*}{ U.S. Corporate Spread } & 0.04 & 0.95 & -0.94 & 0.85 & 0.26 & 0.26 & 0.08 \\
\hline & (1.18) & $(1.02)$ & $(0.65)$ & $(0.69)$ & $(0.57)$ & $(0.16)$ & $(1.05)$ \\
\hline \multirow[t]{2}{*}{ U.S. Yield Gap } & 2.07 & 0.85 & -0.32 & -0.15 & -0.52 & 0.24 & 2.22 \\
\hline & $(2.43)$ & (1.67) & $(0.50)$ & $(0.96)$ & $(0.71)$ & $(0.23)$ & $(1.46)$ \\
\hline \multirow[t]{2}{*}{ Constant } & -4.52 & 5.10 & -4.78 & 5.32 & 1.80 & $1.43^{*}$ & -6.87 \\
\hline & $(14.72)$ & $(12.75)$ & $(9.28)$ & $(4.94)$ & $(4.83)$ & (0.78) & $(7.12)$ \\
\hline Observations & 809 & 809 & 809 & 809 & 758 & 739 & 787 \\
\hline Number of groups & 34 & 34 & 34 & 34 & 33 & 33 & 34 \\
\hline Country Fixed Effects & YES & YES & YES & YES & YES & YES & YES \\
\hline
\end{tabular}

Standard errors in parentheses

*** $p<0.01, * * p<0.05, * p<0.1$ 
Table 4:

Capital Outflows (Share of GDP)

\begin{tabular}{|c|c|c|c|c|c|c|c|}
\hline \multirow[b]{3}{*}{ VARIABLES } & (1) & $(2)$ & (3) & (4) & $(5)$ & (6) & (7) \\
\hline & \multicolumn{7}{|c|}{ 2009Q3-2015Q4 } \\
\hline & Total & Private & FDI & Portfolio & $\begin{array}{c}\text { Portfolio } \\
\text { Debt }\end{array}$ & $\begin{array}{c}\text { Porfolio } \\
\text { Equity }\end{array}$ & Other \\
\hline \multirow[t]{2}{*}{ Growth differential } & -0.04 & -0.06 & 0.02 & -0.00 & 0.02 & -0.02 & -0.05 \\
\hline & $(0.08)$ & $(0.08)$ & $(0.02)$ & $(0.01)$ & $(0.02)$ & $(0.01)$ & $(0.07)$ \\
\hline \multirow[t]{2}{*}{ Interest rate differential } & -0.21 & $-0.28 *$ & 0.08 & $-0.08 * *$ & 0.03 & $-0.10 *$ & $-0.17^{*}$ \\
\hline & $(0.14)$ & $(0.14)$ & $(0.08)$ & $(0.03)$ & $(0.05)$ & $(0.05)$ & $(0.10)$ \\
\hline \multirow[t]{2}{*}{ Trade openness } & 0.06 & 0.07 & 0.03 & 0.02 & 0.01 & 0.01 & 0.03 \\
\hline & $(0.04)$ & $(0.04)$ & $(0.02)$ & $(0.01)$ & $(0.01)$ & $(0.01)$ & $(0.03)$ \\
\hline \multirow[t]{2}{*}{ Reserves } & -0.00 & 0.00 & $0.02 *$ & -0.01 & -0.01 & -0.00 & -0.01 \\
\hline & $(0.02)$ & $(0.02)$ & $(0.01)$ & $(0.01)$ & $(0.01)$ & $(0.00)$ & $(0.02)$ \\
\hline \multirow[t]{2}{*}{ ER Regime } & 0.22 & -0.10 & -0.04 & 0.09 & 0.02 & 0.07 & 0.14 \\
\hline & $(0.34)$ & $(0.42)$ & $(0.06)$ & $(0.15)$ & $(0.14)$ & $(0.11)$ & $(0.44)$ \\
\hline \multirow[t]{2}{*}{ Institutional Quality } & -4.66 & $-6.07 *$ & -0.80 & -0.65 & $1.29 *$ & $-2.07 * * *$ & -2.97 \\
\hline & $(3.76)$ & $(3.35)$ & $(2.22)$ & $(0.58)$ & $(0.65)$ & $(0.51)$ & (3.13) \\
\hline \multirow[t]{2}{*}{ Income per capita } & 0.00 & 0.00 & $0.00 *$ & -0.00 & 0.00 & -0.00 & 0.00 \\
\hline & $(0.00)$ & $(0.00)$ & $(0.00)$ & $(0.00)$ & $(0.00)$ & $(0.00)$ & $(0.00)$ \\
\hline \multirow[t]{2}{*}{ Capital account openness } & $3.80 * *$ & $3.89 * *$ & 0.31 & $1.39 * * *$ & 0.65 & $0.98 * * *$ & 1.50 \\
\hline & $(1.78)$ & $(1.86)$ & $(1.27)$ & $(0.46)$ & $(0.51)$ & $(0.25)$ & $(1.48)$ \\
\hline \multirow[t]{2}{*}{ Financial Development } & -1.25 & -7.98 & -21.74 & -1.59 & $-11.78 *$ & $9.62 * *$ & $27.53^{*}$ \\
\hline & $(17.65)$ & (17.94) & $(19.20)$ & $(5.21)$ & $(6.20)$ & $(4.08)$ & $(14.17)$ \\
\hline \multirow[t]{2}{*}{ Global risk aversion (log) } & 2.17 & 2.13 & $1.92 * *$ & -0.71 & -0.70 & 0.04 & 0.93 \\
\hline & (1.64) & (1.89) & $(0.74)$ & $(0.82)$ & $(0.64)$ & $(0.41)$ & $(1.13)$ \\
\hline \multirow[t]{2}{*}{ Commodity prices (growth) } & $-0.04 * * *$ & $-0.05 * * *$ & $-0.02 * *$ & $-0.01 *$ & $-0.00 * *$ & -0.01 & -0.01 \\
\hline & $(0.01)$ & $(0.01)$ & $(0.01)$ & $(0.01)$ & $(0.00)$ & $(0.00)$ & $(0.01)$ \\
\hline \multirow[t]{2}{*}{ Global liquidity (growth) } & 0.07 & 0.07 & $0.10 * *$ & 0.00 & -0.01 & 0.00 & -0.04 \\
\hline & $(0.08)$ & $(0.08)$ & $(0.04)$ & $(0.03)$ & $(0.02)$ & $(0.02)$ & $(0.05)$ \\
\hline \multirow[t]{2}{*}{ U.S. Corporate Spread } & $-2.17 * *$ & $-2.28 *$ & $-1.31 * *$ & -0.10 & 0.02 & -0.23 & -0.64 \\
\hline & $(1.01)$ & $(1.22)$ & $(0.58)$ & (0.39) & $(0.34)$ & $(0.20)$ & $(0.92)$ \\
\hline \multirow[t]{2}{*}{ U.S. Yield Gap } & 1.10 & $1.75^{*}$ & -0.63 & 0.67 & 0.39 & 0.26 & 0.71 \\
\hline & $(0.82)$ & $(0.91)$ & $(0.42)$ & $(0.45)$ & $(0.31)$ & $(0.23)$ & $(0.55)$ \\
\hline \multirow[t]{2}{*}{ Constant } & -7.69 & -6.66 & 1.05 & 2.91 & 5.05 & -1.96 & -13.15 \\
\hline & (10.19) & (9.79) & $(7.92)$ & (3.12) & (3.00) & (2.11) & (7.83) \\
\hline Observations & 809 & 809 & 809 & 809 & 753 & 752 & 787 \\
\hline Number of groups & 34 & 34 & 34 & 34 & 34 & 34 & 34 \\
\hline Country Fixed Effects & YES & YES & YES & YES & YES & YES & YES \\
\hline
\end{tabular}

Standard errors in parentheses

*** $p<0.01, * * p<0.05, * p<0.1$ 
To get a sense of the economic significance or magnitude of the impact of the independent variables towards explaining capital flows, Figure 1 shows the contribution of some of the key variables. The contribution is basically the coefficient of the respective independent variables multiplied by the average value of the independent variable for the period 2009Q3-2015Q44. This exercise is particularly important in understanding the reasons behind the capital flow slowdown witnessed in recent data. The results suggest that the positive interest rate differential, particularly on the back of ultra-low interest rates in the U.S., has helped EMDEs to attract flows. This effect can be found in net as well as gross inflows and outflows, particularly for other investment flows. On the other hand, global risk aversion has been a key factor in reducing capital flows to EMDEs. In line with the finding of IMF (2016a), the contribution from commodity prices is low.

What is striking in the charts of Figure 1 is that, despite having a positive coefficient, the contribution from growth differential is low. This factor is clearly displayed in Figure 2, that shows the evolution of the contribution of growth differential and global risk aversion in the period 2009Q3-2015Q4 for net private flows 5 . The contribution of global risk aversion, albeit negative, has been steady over time. The impact of growth differential has fallen from the local peak of around 4 percent of GDP towards the beginning of the time period to less than 1 percent of GDP in recent times. The contribution of growth differential has also declined when looking at the maximum and median growth differential of the sample over time. These findings are in line with IMF (2016a) that find that much of the decline in inflows can be explained by the narrowing differential in growth prospects between emerging markets and advanced economies.

\footnotetext{
${ }^{4}$ The average growth differential corresponds to the difference between real GDP growth of EMDE (as aggregated by the IMF WEO database) and the U.S. For interest rate differential, the average value across the countries for the period 2009Q3-2015Q4 is computed.

5 The EMDE growth differential in Figure 2 corresponds to the difference between real GDP growth of EMDE (as aggregated by the IMF WEO database) and the U.S. The median growth differential is calculated using the median EMDE from the sample. Similarly, the maximum and minimum growth differentials are computed using the maximum and minimum from the sample.
} 
Figure 1: Contribution of Key Push and Pull Factors

Contribution of each variable is the coefficient from Table 1 for each variable, multiplied by the average value of the variable in the period 2009Q3-2015Q4.
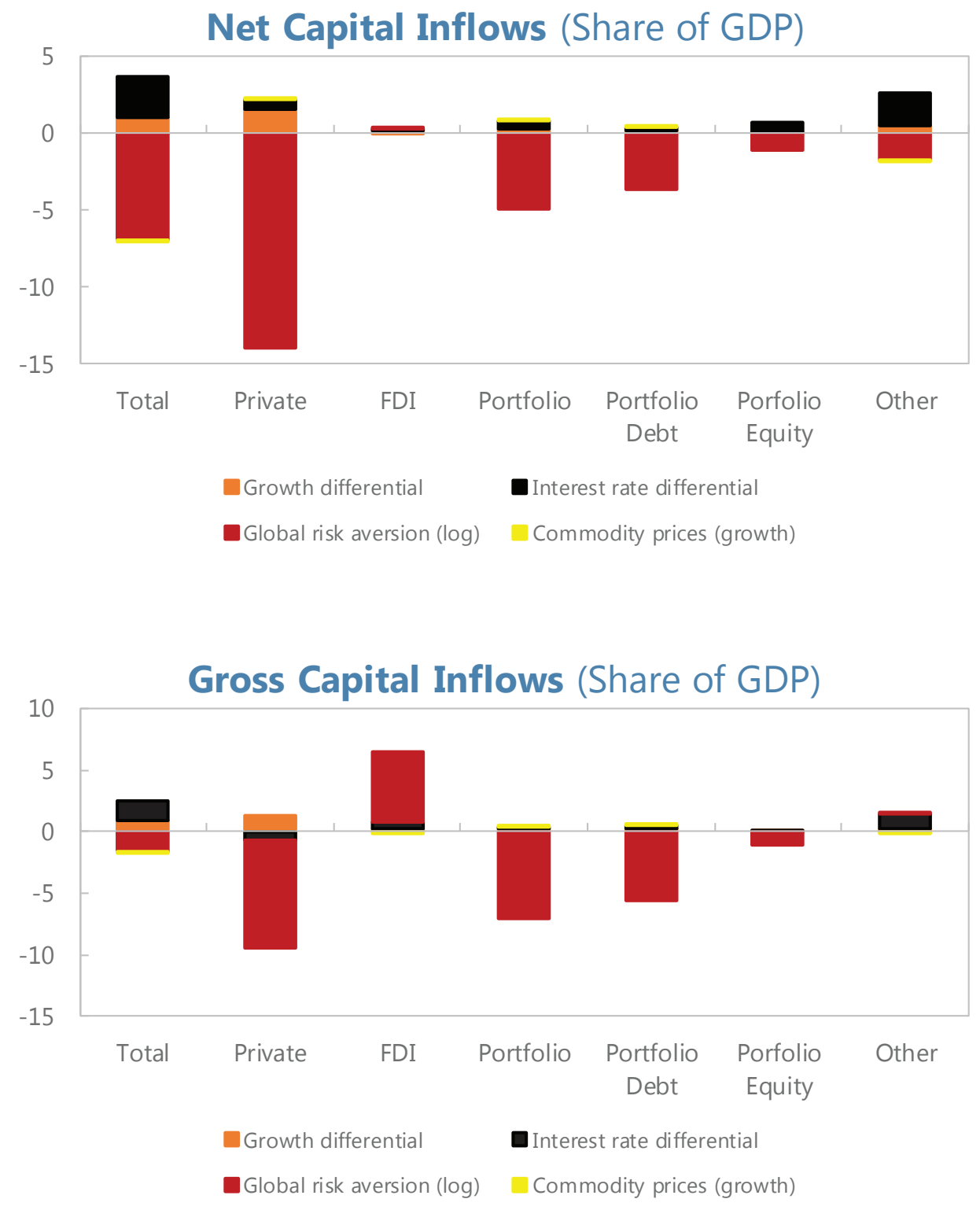

CInternational Monetary Fund. Not for Redistribution 


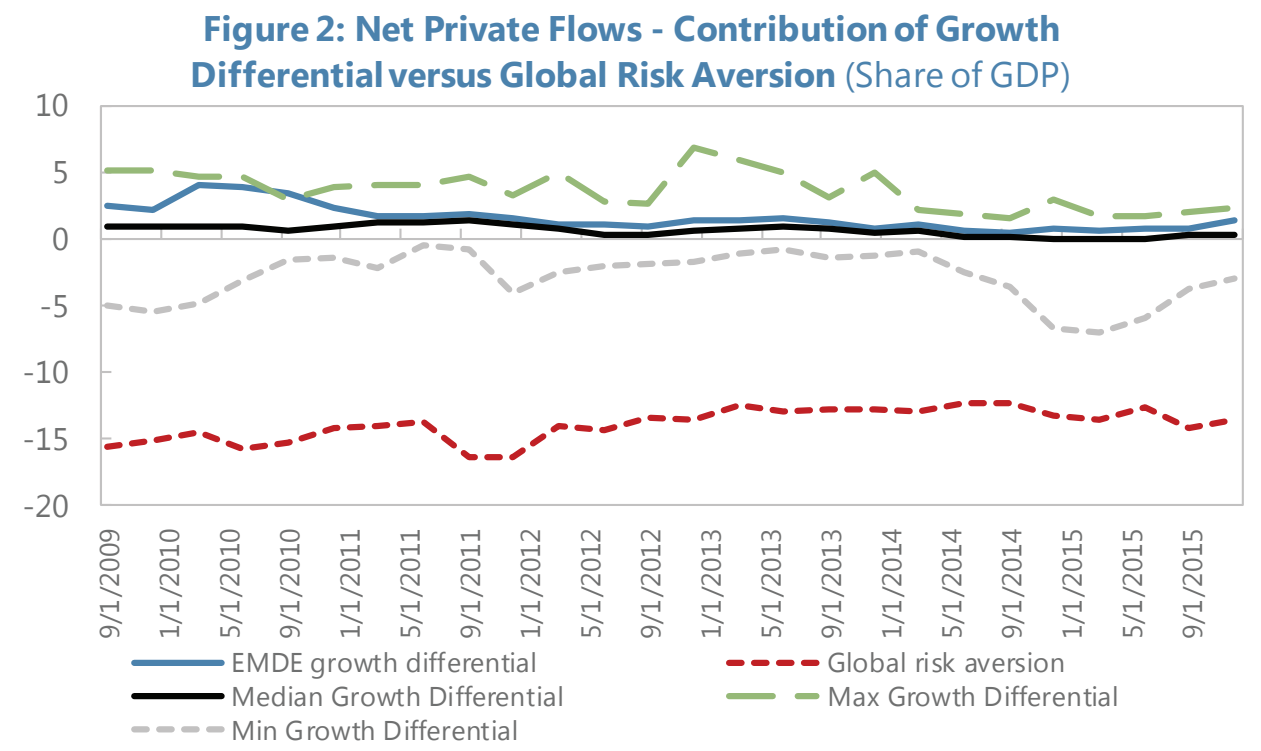

\section{B. High and Low Episodes}

In this section, the results for regression analysis using high and low episodes are reported. Figure 3 reports the coefficients of some selected important independent variables when the dependent variable is key components of net flows. Appendix III shows similar charts when gross capital inflows and gross capital outflows are considered as dependent variables. In addition, Appendix III also reports the tables showing the underlying regression tables including all the dependent variables.

Push/pull factors: The sensitivity of capital flows towards growth differentials increases during high episodes, and this effect is statistically significant for private flows and portfolio equity flows. A one percentage point increase in growth differentials vis-à-vis the U.S. increase net private flows by 0.73 percent of GDP during high episodes, compared to 0.38 percent of GDP in the baseline. The charts and tables in Appendix III show that this effect is mainly due to the gross capital inflows rather than outflows. Interestingly, though statistically significant for baseline cases, the coefficients of growth differentials are not significant for high or low episodes when net portfolio or net other investment flows are considered. The coefficient of growth differential is statistically significant for low episodes when net FDI is considered. 
The sensitivity of capital flows towards interest rate differentials increases during both high and low episodes for net portfolio equity, with a one percentage point rise in interest rate differential increasing net portfolio equity flows by 0.68 and 0.21 percent of GDP during high and low episodes respectively, compared to 0.12 percent of GDP during baseline case. This effect is mainly due to the higher sensitivity of gross portfolio equity inflows during high episodes. On the other hand, the sensitivity of net other investment flows towards interest rate differentials decrease during high and low episodes.

Structural factors: The results suggest that the coefficients are higher for trade openness during high episodes, and this impact is evident across all sorts of instruments with the exception of FDI. This suggests that more trade open economies receive higher net flows during high and low capital flows episodes. On the flip side, more open economies also tend to have negative net flows during low episodes, an impact that is significant for total, private and FDI flows.

The tables in Appendix III also reveal some interesting heterogeneous response of different types of flows towards other structural factors during high and low episodes. For example, more financially developed economies tend to have higher net portfolio debt flows but less net other investment flows during low episodes. What is also striking is the lack of statistical significance in a lot of structural factors, indicating that high and low episodes are not necessarily driven by structural factors. For example, reserves are statistically significant for net total flows when the baseline is considered, but not when high episodes are considered.

Push factors: While the coefficients of global risk aversion are statistically significant for a lot of instruments (in net terms) during low and high episodes, the magnitude is either lower or similar to the baseline case. The exception is net portfolio debt where the coefficient is more negative during low episodes. Interestingly, the coefficient of global risk aversion for gross FDI inflows increases significantly during high episodes, reflecting investors' preference for FDI when risk aversion increases.

The more striking results come from the coefficients of the U.S. yield gap - the coefficients are more negative for net flows during high episodes. This is particularly 
interesting since, with the exception of net FDI, the indicator is not statistically significant for the baseline case. However, the indicator is statistically significant for high episodes across all instruments, with the exception of net FDI and net other investment flows. Appendix III shows that this impact is predominantly due to the impact of the U.S. yield gap on gross capital inflows, but gross capital outflows also contribute.

Overall, the results of the analysis on high and low capital flows episodes suggest that some instruments can be more sensitive towards both push and pull factors during high and low episodes. Interestingly, the increased sensitivity for push factors do not necessarily come from global risk aversion, but from the U.S. yield gap and the U.S. corporate spread. 


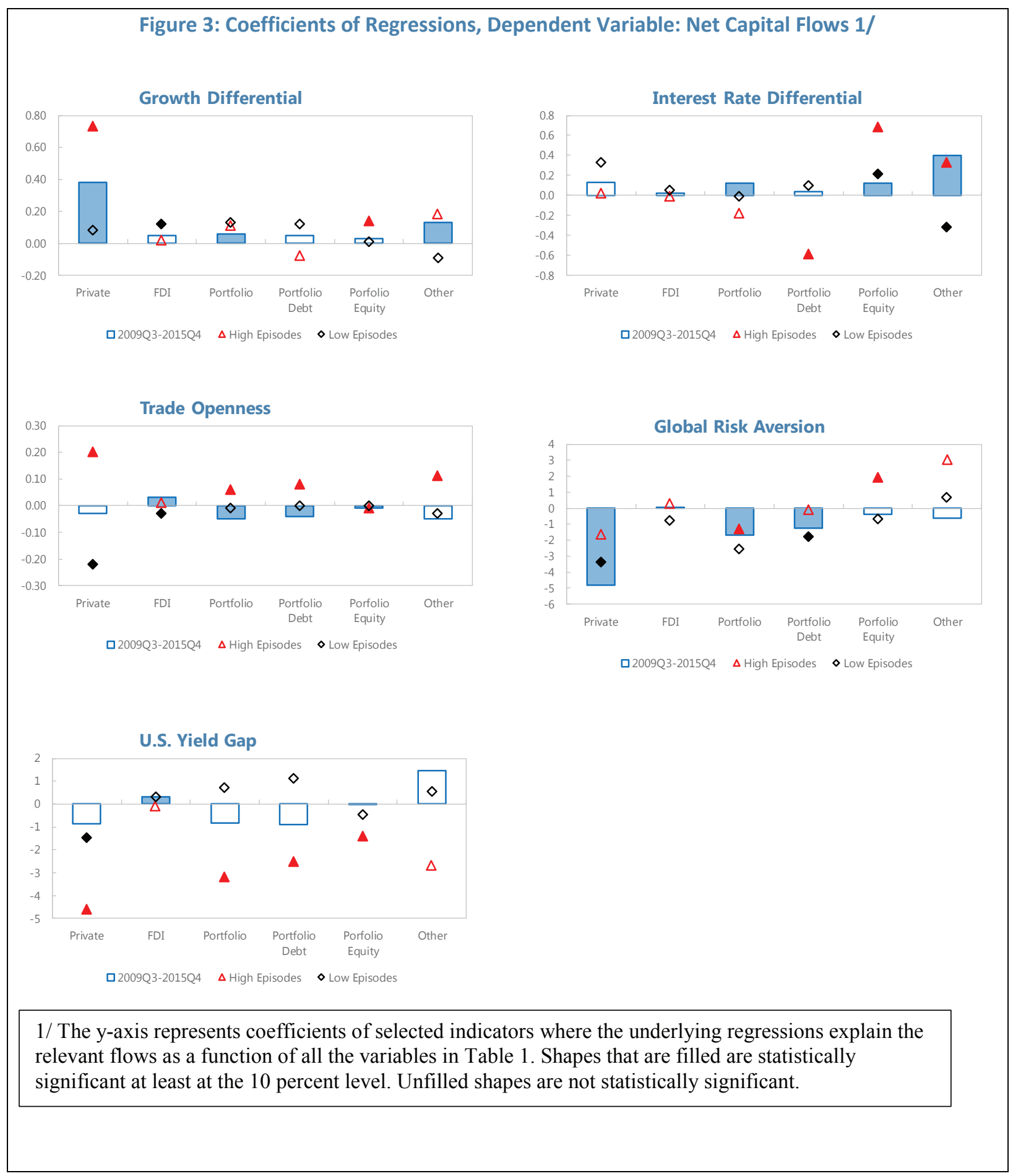

CInternational Monetary Fund. Not for Redistribution 


\section{Robustness}

A host of robustness checks was performed to ascertain the validity of the main findings, both for baseline and high and low episode regressions. To start off, the growth and interest rate differentials vis-à-vis advanced economies (instead of the U.S.) were used in the regressions. Another set of robustness tests included the U.S. shadow rate, instead of the U.S. policy rate. Unlike the observed short-term interest rate, the shadow rate is not bounded below by zero percent, and can thus be a better measure of the U.S. monetary policy stance in the current context of ultra-low policy rate. The key results are robust to these alternative specifications.

It must be noted that, while analyzing extreme capital flow episodes, the literature has usually either used certain percentile of the distribution or certain number of standard deviations above and below mean. Hence, in addition to the aforementioned robustness checks, two alternative definitions of high and low episodes were used. The first case defined high episode as three consecutive quarters where flows are 0.5 standard deviation higher than mean, and vice versa for low episodes. The second case defined high and low episodes as the top $30^{\text {th }}$ and bottom $30^{\text {th }}$ percentile of the distribution of capital flows, respectively. Broadly speaking, the key messages of the analysis are robust to these specifications.

\section{Conclusion}

Recent studies have pointed out various aspects of capital flows that need to be taken into consideration in order to understand the determinants of capital flows. This paper is an attempt to bring all the nuances under one roof by analyzing the drivers of capital flows, in both net and gross terms, across a wide range of instruments, comprising private, FDI, portfolio, portfolio debt, portfolio equity, and other investment flows. The time period considered is also post crisis and thus helps to evaluate the recent drivers of capital flows.

The results show that both push and pull factors are important drivers for capital flows. However, there is considerable variation across the type of instruments and the type of flows (net or gross). The sensitivity of some instruments towards push and pull factors increases during periods of high and low capital flows. Moreover, some variables may not necessarily be significant during normal times, but can be important drivers during high and low episodes, and vice versa. Overall, the results imply that the capital flows slowdown 
witnessed in recent years is due to a combination of low growth prospects of recipient countries and worse global risk sentiment.

\section{REFERENCES}

Ahmed, Shagil, and Andrei Zlate, 2014, "Capital flows to emerging market economies: A brave new world?" Journal of International Money and Finance, Vol. 48, pp. 221-248.

Ahmed, Swarnali, 2015, "If the Fed Acts, How Do You Reacts? The Liftoff Effect on Capital Flows,” IMF Working Paper No. 15/256 (Washington: International Monetary Fund).

Broner, Fernando, Tatiana Didier, Aitor Erce, and Sergio Schmukler, 2013, "Gross capital flows: Dynamics and crises," Journal of Monetary Economics, Vol. 60(1), pp. 113133.

Calvo, Guillermo, 1998, "Capital flows and capital-market crises: the simple economics of sudden stops," Journal of Applied Economics, Vol. 1(1), pp. 35-54.

Forbes, Kristin J., and Frank E. Warnock, 2012, “Capital flow waves: surges, stops, flight, and retrenchment," Journal of International Economics, Vol. 88(2), pp. 235-251.

Ghosh, Atish R., Mahvash S. Qureshi, Jun II Kim, and Juan Zalduendo, 2014, "Surges," Journal of International Economics, Vol. 92(2), pp. 266-285.

IMF, 2011a, "International Capital Flows: Reliable or Fickle?" World Economic Outlook, International Monetary Fund, Chapter 4, April 2011.

IMF, 2011b, "Recent Experiences in Managing Capital Inflows - Cross-Cutting Themes and

Possible Policy Framework," IMF Board Paper, International Monetary Fund.

IMF, 2016a, "Understanding the Slowdown in Capital Flows in Emerging Markets," World Economic Outlook, International Monetary Fund, Chapter 2, April 2016.

IMF, 2016b, "Capital Flows - Review of Experience with the Institutional View," IMF Board Paper, International Monetary Fund.

Koepke, Robin, 2015, "What Drives Capital Flows to Emerging Markets? A Survey of the Empirical Literature," Institute of International Finance.

Nier, Erlend, Tahsin S. Sedik, and Tomas Mondino, 2014, "Gross Private Capital Flows to Emerging Markets: Can the Global Financial Cycle Be Tamed?” IMF Working Paper No. 14/196 (Washington: International Monetary Fund). 
Pagliari, Maria S., and Swarnali A. Hannan, 2017 (forthcoming), “The Volatility of Capital Flows in Emerging Markets: Measures and Determinants," IMF Working Paper (Washington: International Monetary Fund).

\section{APPENDICES}

\section{A. Appendix I - List of Countries}

Albania, Brazil, Bulgaria, Chile, China, Colombia, Costa Rica, Croatia, Ecuador, Egypt, El Salvador, Guatemala, Hungary, India, Indonesia, Jordan, Kazakhstan, Latvia, Lithuania, Macedonia, FYR, Malaysia, Mexico, Paraguay, Peru, Philippines, Poland, Russia, Saudi Arabia, South Africa, Sri Lanka, Thailand, Turkey, Ukraine, Uruguay.

\section{B. Appendix II - Data Sources}

\begin{tabular}{|c|c|}
\hline Variables & Sources \\
\hline Capital flow variables & $\begin{array}{l}\text { Financial Flow Analytics Database compiled } \\
\text { from the IMF's Balance of Payments } \\
\text { Statistics, International Financial Statistics, } \\
\text { and World Economic Outlook databases, } \\
\text { World Bank's World Development } \\
\text { Indicators database, Haver Analytics, CEIC } \\
\text { Asia database, and CEIC China database. }\end{array}$ \\
\hline $\begin{array}{l}\text { Real GDP growth, interest rate, trade } \\
\text { openness, reserves, income per capita, } \\
\text { commodity prices, U.S. Yield Gap }\end{array}$ & IMF WEO database, IFS, national sources. \\
\hline Exchange rate regime & IMF AREAER and Coarse Classification. \\
\hline Institutional quality & $\begin{array}{l}\text { Rule of law measure from World Bank's } \\
\text { Worldwide Governance Indicators. }\end{array}$ \\
\hline Capital account openness & $\begin{array}{l}\text { Chinn and Ito (2006), updated version of } \\
\text { the database. }\end{array}$ \\
\hline Financial development & $\begin{array}{l}\text { Svirydzenka, K. (2016), “Introducing a New } \\
\text { Broad-based Index of Financial } \\
\text { Development”, IMF Working Paper No. } \\
\text { 16/5. }\end{array}$ \\
\hline Global risk aversion & $\begin{array}{l}\text { CBOE Market Volatility Index (VIX), } \\
\text { downloaded from Haver Analytics. }\end{array}$ \\
\hline
\end{tabular}




\begin{tabular}{|l|l|}
\hline Global liquidity & $\begin{array}{l}\text { Growth of G7 M2, IMF and national } \\
\text { sources. }\end{array}$ \\
\hline U.S. Corporate Spread & Federal Reserve (FRED). \\
\hline U.S. Shadow Rate & $\begin{array}{l}\text { Wu-Xia Shadow Federal Funds Rate from } \\
\text { Federal Reserve Bank of Atlanta, } \\
\text { downloaded from Haver Analytics. }\end{array}$ \\
\hline
\end{tabular}

\section{Appendix III - Results of High/Low Episodes}

\section{Charts}

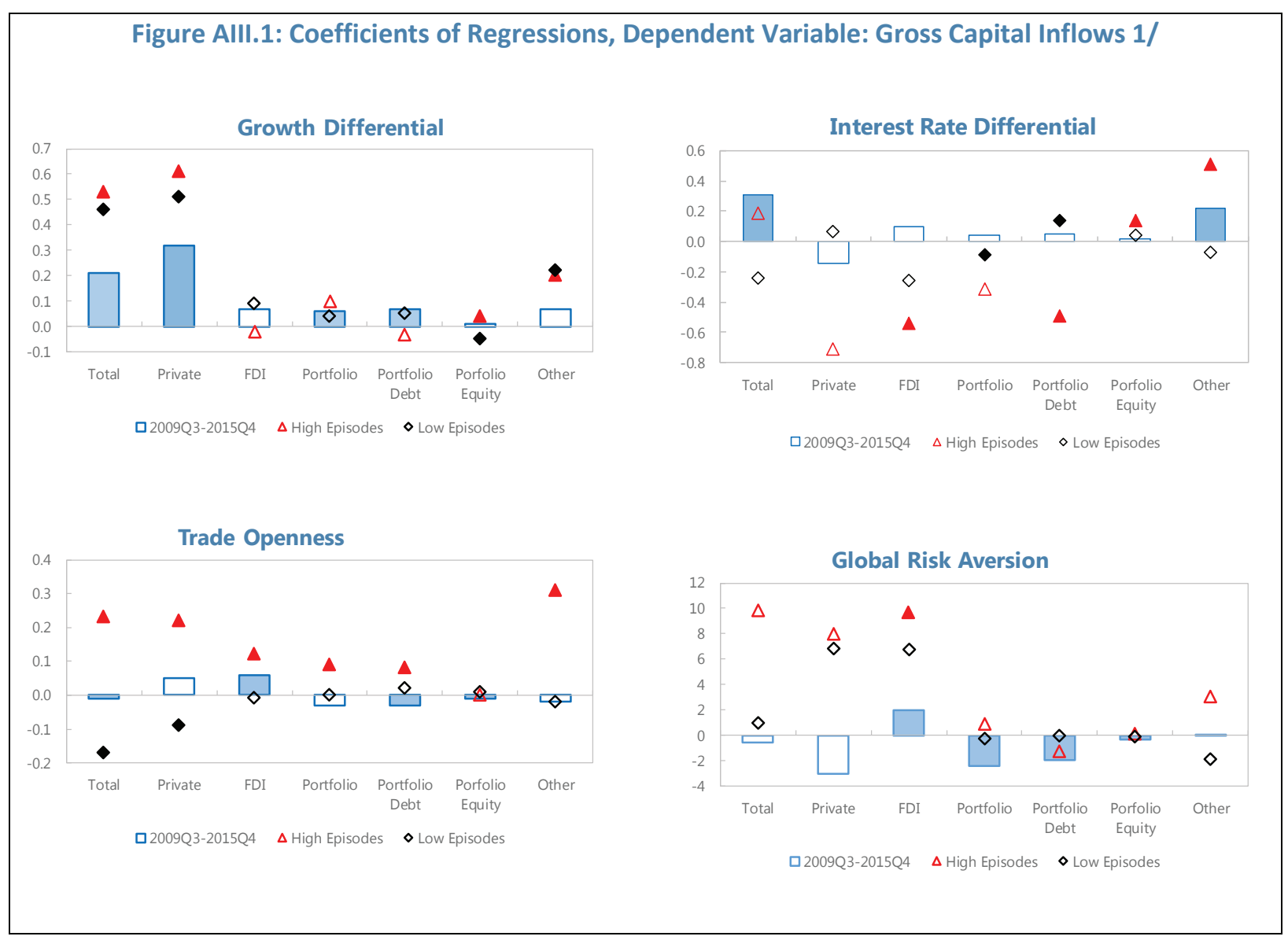



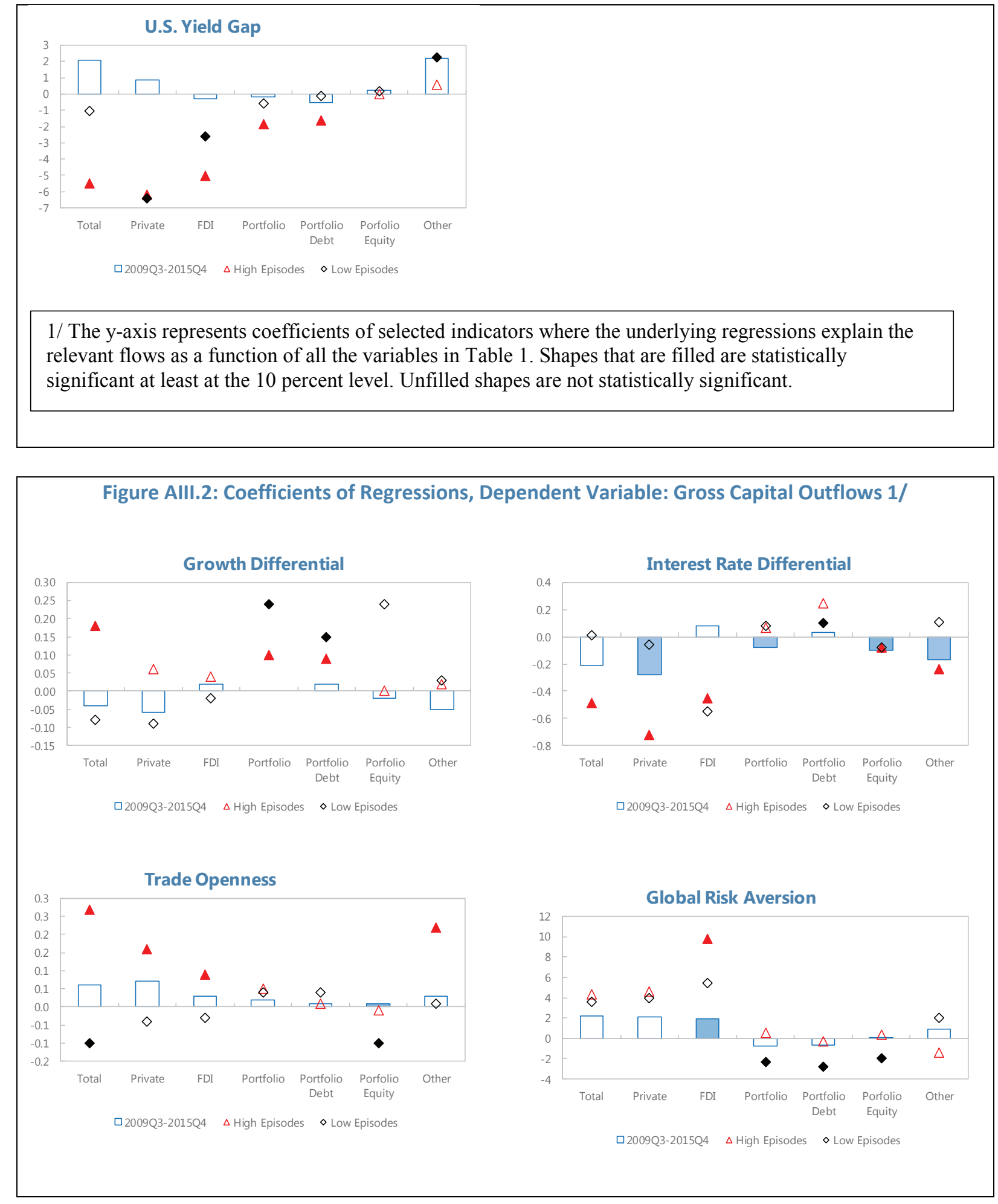

CInternational Monetary Fund. Not for Redistribution 


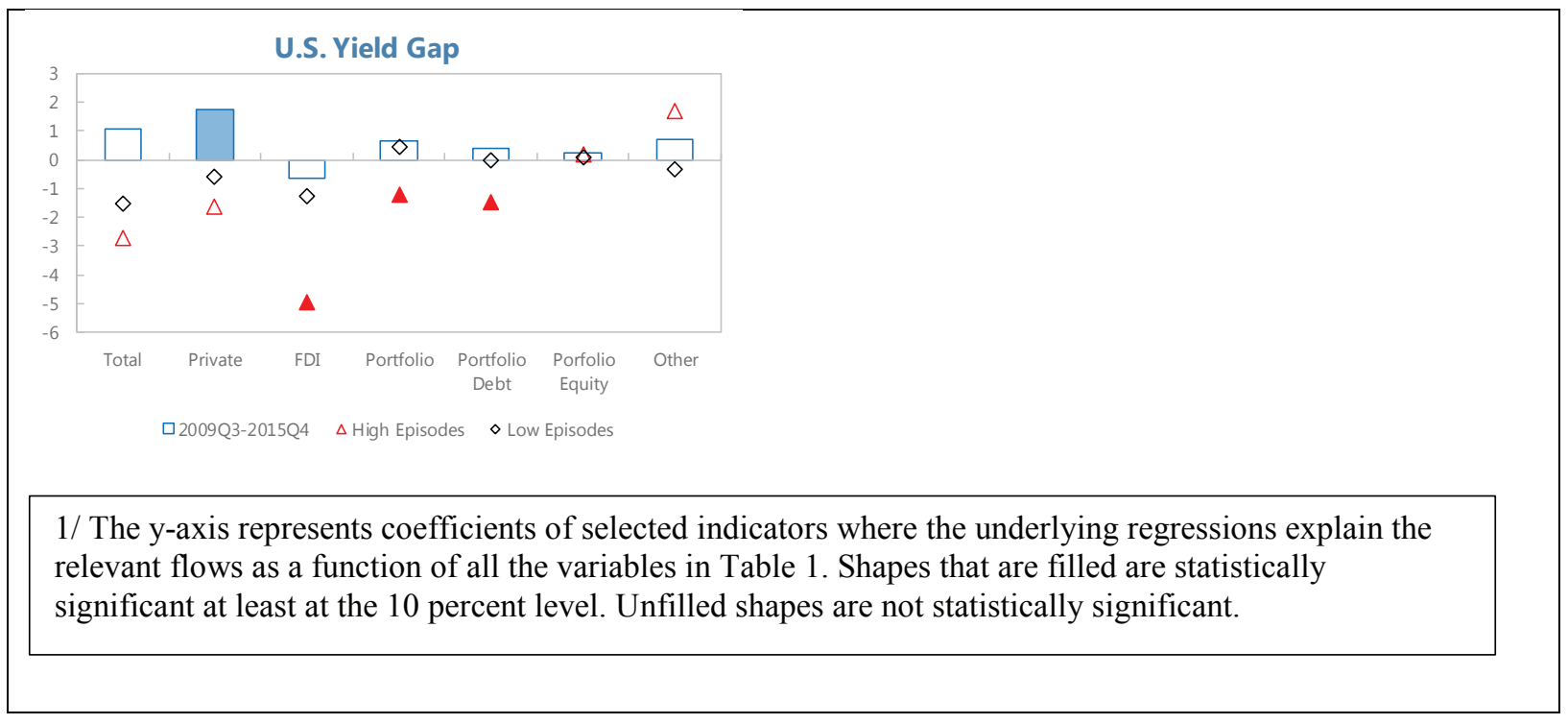

Tables

Table AIII.1

\begin{tabular}{|c|c|c|c|c|c|c|c|c|c|c|c|c|c|c|}
\hline \multirow[b]{4}{*}{ VARIABLES } & \multicolumn{14}{|c|}{ Net Capital Flows (Share of GDP) } \\
\hline & (1) & (2) & (3) & (4) & (5) & (6) & (7) & (8) & (9) & (10) & (11) & (12) & (13) & (14) \\
\hline & \multicolumn{7}{|c|}{ High Episodes } & \multicolumn{7}{|c|}{ Low Episodes } \\
\hline & Total & Private & FDI & Portfolio & $\begin{array}{c}\begin{array}{c}\text { Portfolio } \\
\text { Debt }\end{array} \\
\end{array}$ & $\begin{array}{c}\text { Porfolio } \\
\text { Equity }\end{array}$ & Other & Total & Private & FDI & Portfolio & $\begin{array}{c}\text { Portfolio } \\
\text { Debt }\end{array}$ & $\begin{array}{c}\text { Porfolio } \\
\text { Equity }\end{array}$ & Other \\
\hline Growth differential & $\begin{array}{l}0.33^{*} \\
(0.16)\end{array}$ & $\begin{array}{c}0.73^{* * *} \\
(0.14)\end{array}$ & $\begin{array}{c}0.02 \\
(0.04)\end{array}$ & $\begin{array}{c}0.11 \\
(0.09)\end{array}$ & $\begin{array}{l}-0.08 \\
(0.08)\end{array}$ & $\begin{array}{l}0.14^{* *} \\
(0.07)\end{array}$ & $\begin{array}{c}0.18 \\
(0.13)\end{array}$ & $\begin{array}{l}0.23^{* *} \\
(0.09)\end{array}$ & $\begin{array}{c}0.08 \\
(0.13)\end{array}$ & $\begin{array}{c}0.12^{* * *} \\
(0.04)\end{array}$ & $\begin{array}{c}0.13 \\
(0.09)\end{array}$ & $\begin{array}{c}0.12 \\
(0.11)\end{array}$ & $\begin{array}{c}0.01 \\
(0.04)\end{array}$ & $\begin{array}{l}-0.09 \\
(0.06)\end{array}$ \\
\hline Interest rate differential & $\begin{array}{l}0.43^{* *} \\
(0.18)\end{array}$ & $\begin{array}{c}0.02 \\
(0.23)\end{array}$ & $\begin{array}{l}-0.01 \\
(0.05)\end{array}$ & $\begin{array}{l}-0.18 \\
(0.22)\end{array}$ & $\begin{array}{c}-0.59 * * * \\
(0.19)\end{array}$ & $\begin{array}{l}0.68^{* *} \\
(0.26)\end{array}$ & $\begin{array}{l}0.33^{* *} \\
(0.15)\end{array}$ & $\begin{array}{c}0.21 \\
(0.24)\end{array}$ & $\begin{array}{c}0.33 \\
(0.20)\end{array}$ & $\begin{array}{c}0.05 \\
(0.08)\end{array}$ & $\begin{array}{l}-0.01 \\
(0.05)\end{array}$ & $\begin{array}{c}0.10 \\
(0.10)\end{array}$ & $\begin{array}{l}0.21^{* *} \\
(0.09)\end{array}$ & $\begin{array}{c}-0.32 * * \\
(0.13)\end{array}$ \\
\hline Trade openness & $\begin{array}{l}0.06^{* *} \\
(0.03)\end{array}$ & $\begin{array}{c}0.20^{* * *} \\
(0.06)\end{array}$ & $\begin{array}{c}0.01 \\
(0.02)\end{array}$ & $\begin{array}{l}0.06^{* *} \\
(0.03)\end{array}$ & $\begin{array}{l}0.08^{* *} \\
(0.03)\end{array}$ & $\begin{array}{c}-0.01^{* *} \\
(0.01)\end{array}$ & $\begin{array}{c}0.11^{* * *} \\
(0.04)\end{array}$ & $\begin{array}{c}-0.13^{* * *} \\
(0.04)\end{array}$ & $\begin{array}{c}-0.22 * * * \\
(0.03)\end{array}$ & $\begin{array}{c}-0.03^{* *} \\
(0.01)\end{array}$ & $\begin{array}{l}-0.01 \\
(0.03)\end{array}$ & $\begin{array}{l}-0.00 \\
(0.03)\end{array}$ & $\begin{array}{c}0.00 \\
(0.01)\end{array}$ & $\begin{array}{l}-0.03 \\
(0.03)\end{array}$ \\
\hline Reserves & $\begin{array}{c}0.03 \\
(0.07)\end{array}$ & $\begin{array}{l}-0.04 \\
(0.03)\end{array}$ & $\begin{array}{l}0.03^{* *} \\
(0.01)\end{array}$ & $\begin{array}{c}0.06^{* * *} \\
(0.01)\end{array}$ & $\begin{array}{c}0.05^{* * *} \\
(0.02)\end{array}$ & $\begin{array}{c}0.02^{* * *} \\
(0.01)\end{array}$ & $\begin{array}{l}-0.02 \\
(0.07)\end{array}$ & $\begin{array}{l}0.04^{*} \\
(0.02)\end{array}$ & $\begin{array}{c}0.02 \\
(0.02)\end{array}$ & $\begin{array}{l}-0.00 \\
(0.01)\end{array}$ & $\begin{array}{l}0.01^{*} \\
(0.01)\end{array}$ & $\begin{array}{c}0.00 \\
(0.01)\end{array}$ & $\begin{array}{l}-0.01 \\
(0.01)\end{array}$ & $\begin{array}{c}0.02 \\
(0.02)\end{array}$ \\
\hline ER Regime & $\begin{array}{l}-0.81 \\
(0.57)\end{array}$ & $\begin{array}{l}-0.18 \\
(0.66)\end{array}$ & $\begin{array}{l}0.39^{* *} \\
(0.16)\end{array}$ & $\begin{array}{l}-0.90^{*} \\
(0.44)\end{array}$ & $\begin{array}{c}-0.71^{* *} \\
(0.34)\end{array}$ & $\begin{array}{l}-0.56 \\
(0.42)\end{array}$ & $\begin{array}{c}0.51 \\
(0.42)\end{array}$ & $\begin{array}{l}-0.45 \\
(0.43)\end{array}$ & $\begin{array}{l}-1.68^{*} \\
(0.97)\end{array}$ & $\begin{array}{c}0.29 \\
(0.31)\end{array}$ & $\begin{array}{c}-0.89^{* * *} \\
(0.20)\end{array}$ & $\begin{array}{l}-0.09 \\
(0.28)\end{array}$ & $\begin{array}{l}-0.16 \\
(0.17)\end{array}$ & $\begin{array}{l}-0.41 \\
(0.28)\end{array}$ \\
\hline Institutional Quality & $\begin{array}{l}2.18 \\
(2.87)\end{array}$ & $\begin{array}{l}-2.30 \\
(3.31)\end{array}$ & $\begin{array}{c}-3.53^{* * *} \\
(1.24)\end{array}$ & $\begin{array}{c}4.14 \\
(2.78)\end{array}$ & $\begin{array}{l}-2.18 \\
(3.05)\end{array}$ & $\begin{array}{l}2.56 \\
(2.63)\end{array}$ & $\begin{array}{l}11.63^{*} \\
(5.98)\end{array}$ & $\begin{array}{l}1.24 \\
(4.91)\end{array}$ & $\begin{array}{c}-12.74^{* * *} \\
(4.30)\end{array}$ & $\begin{array}{l}0.08 \\
(2.19)\end{array}$ & $\begin{array}{l}5.93^{*} \\
(3.05)\end{array}$ & $\begin{array}{l}-5.64^{*} \\
(2.79)\end{array}$ & $\begin{array}{c}2.75 \\
(1.80)\end{array}$ & $\begin{array}{l}7.08^{* *} \\
(3.23)\end{array}$ \\
\hline Income per capita & $\begin{array}{c}0.00^{* * *} \\
(0.00)\end{array}$ & $\begin{array}{l}0.00^{*} \\
(0.00)\end{array}$ & $\begin{array}{l}-0.00^{*} \\
(0.00)\end{array}$ & $\begin{array}{c}0.00 \\
(0.00)\end{array}$ & $\begin{array}{l}-0.00 \\
(0.00)\end{array}$ & $\begin{array}{c}0.00 \\
(0.00)\end{array}$ & $\begin{array}{c}0.00 \\
(0.00)\end{array}$ & $\begin{array}{c}0.00 \\
(0.00)\end{array}$ & $\begin{array}{l}-0.00 \\
(0.00)\end{array}$ & $\begin{array}{l}-0.00 \\
(0.00)\end{array}$ & $\begin{array}{c}0.00 \\
(0.00)\end{array}$ & $\begin{array}{l}-0.00 \\
(0.00)\end{array}$ & $\begin{array}{c}0.00 \\
(0.00)\end{array}$ & $\begin{array}{l}0.00^{* *} \\
(0.00)\end{array}$ \\
\hline Capital account openness & $\begin{array}{l}-1.82 \\
(3.60)\end{array}$ & $\begin{array}{l}-0.22 \\
(4.19)\end{array}$ & $\begin{array}{c}-1.42^{* *} \\
(0.66)\end{array}$ & $\begin{array}{l}-2.41 \\
(1.97)\end{array}$ & $\begin{array}{c}3.31 \\
(3.56)\end{array}$ & $\begin{array}{l}-1.28 \\
(1.23)\end{array}$ & $\begin{array}{c}0.04 \\
(2.48)\end{array}$ & $\begin{array}{l}-0.89 \\
(2.29)\end{array}$ & $\begin{array}{l}-3.84 \\
(3.35)\end{array}$ & $\begin{array}{l}1.41 \\
(1.43)\end{array}$ & $\begin{array}{c}3.68 \\
(2.37)\end{array}$ & $\begin{array}{l}2.70^{*} \\
(1.56)\end{array}$ & $\begin{array}{l}-1.64^{*} \\
(0.82)\end{array}$ & $\begin{array}{l}-2.31^{*} \\
(1.28)\end{array}$ \\
\hline Financial Development & $\begin{array}{c}14.81 \\
(15.75)\end{array}$ & $\begin{array}{c}-1.12 \\
(19.20)\end{array}$ & $\begin{array}{l}-4.51 \\
(8.55)\end{array}$ & $\begin{array}{l}-13.37 \\
(10.30)\end{array}$ & $\begin{array}{l}-6.14 \\
(8.62)\end{array}$ & $\begin{array}{c}-19.57^{* * *} \\
(6.57)\end{array}$ & $\begin{array}{l}-8.50 \\
(14.47)\end{array}$ & $\begin{array}{l}-36.95^{*} \\
(20.43)\end{array}$ & $\begin{array}{c}-4.01 \\
(13.04)\end{array}$ & $\begin{array}{l}-4.94 \\
(6.21)\end{array}$ & $\begin{array}{l}-0.03 \\
(9.47)\end{array}$ & $\begin{array}{c}25.49 * * * \\
(7.59)\end{array}$ & $\begin{array}{c}0.85 \\
(6.84)\end{array}$ & $\begin{array}{c}-44.25^{* * *} \\
(13.38)\end{array}$ \\
\hline Global risk aversion (log) & $\begin{array}{l}6.43^{* *} \\
(2.99)\end{array}$ & $\begin{array}{l}-1.67 \\
(2.63)\end{array}$ & $\begin{array}{c}0.27 \\
(0.59)\end{array}$ & $\begin{array}{l}-1.30 \\
(1.46)\end{array}$ & $\begin{array}{l}-0.13 \\
(2.29)\end{array}$ & $\begin{array}{l}1.92^{* *} \\
(0.90)\end{array}$ & $\begin{array}{c}3.04 \\
(3.02)\end{array}$ & $\begin{array}{c}-3.83^{* * *} \\
(0.99)\end{array}$ & $\begin{array}{c}-3.40^{* * *} \\
(1.15)\end{array}$ & $\begin{array}{l}-0.80 \\
(0.47)\end{array}$ & $\begin{array}{l}-2.57^{* *} \\
(1.00)\end{array}$ & $\begin{array}{c}-1.81^{* *} \\
(0.75)\end{array}$ & $\begin{array}{l}-0.71 \\
(0.46)\end{array}$ & $\begin{array}{c}0.67 \\
(0.82)\end{array}$ \\
\hline Commodity prices (growth) & $\begin{array}{c}-0.01 \\
(0.03)\end{array}$ & $\begin{array}{c}0.06^{* * *} \\
(0.02)\end{array}$ & $\begin{array}{l}0.01^{*} \\
(0.00)\end{array}$ & $\begin{array}{c}0.07 * * * \\
(0.02)\end{array}$ & $\begin{array}{c}0.06^{* * *} \\
(0.01)\end{array}$ & $\begin{array}{c}0.00 \\
(0.01)\end{array}$ & $\begin{array}{c}-0.03 \\
(0.02)\end{array}$ & $\begin{array}{l}0.03^{*} \\
(0.02)\end{array}$ & $\begin{array}{l}0.00 \\
(0.01)\end{array}$ & $\begin{array}{c}-0.01^{* *} \\
(0.00)\end{array}$ & $\begin{array}{c}0.00 \\
(0.01)\end{array}$ & $\begin{array}{l}-0.00 \\
(0.00)\end{array}$ & $\begin{array}{c}0.02^{* * *} \\
(0.00)\end{array}$ & $\begin{array}{l}-0.02 \\
(0.02)\end{array}$ \\
\hline Global liquidity (growth) & $\begin{array}{c}0.22 \\
(0.16)\end{array}$ & $\begin{array}{c}-0.03 \\
(0.22)\end{array}$ & $\begin{array}{c}-0.02 \\
(0.05)\end{array}$ & $\begin{array}{c}0.14 \\
(0.09)\end{array}$ & $\begin{array}{l}-0.01 \\
(0.10)\end{array}$ & $\begin{array}{c}0.07 \\
(0.07)\end{array}$ & $\begin{array}{c}0.09 \\
(0.11)\end{array}$ & $\begin{array}{c}-0.01 \\
(0.07)\end{array}$ & $\begin{array}{c}0.23^{* * *} \\
(0.06)\end{array}$ & $\begin{array}{c}0.02 \\
(0.02)\end{array}$ & $\begin{array}{l}-0.04 \\
(0.04)\end{array}$ & $\begin{array}{c}-0.10^{* * *} \\
(0.03)\end{array}$ & $\begin{array}{l}-0.03 \\
(0.02)\end{array}$ & $\begin{array}{c}0.02 \\
(0.06)\end{array}$ \\
\hline U.S. Corporate Spread & $\begin{array}{c}-6.46^{* * *} \\
(1.31)\end{array}$ & $\begin{array}{c}-3.09 * * * \\
(1.06)\end{array}$ & $\begin{array}{c}-1.04^{* * *} \\
(0.30)\end{array}$ & $\begin{array}{l}-1.41^{*} \\
(0.73)\end{array}$ & $\begin{array}{c}-2.10^{* *} \\
(0.81)\end{array}$ & $\begin{array}{c}-2.03^{* * *} \\
(0.51)\end{array}$ & $\begin{array}{c}-4.37^{* * *} \\
(1.29)\end{array}$ & $\begin{array}{c}0.24 \\
(0.82)\end{array}$ & $\begin{array}{l}-0.31 \\
(1.21)\end{array}$ & $\begin{array}{c}0.21 \\
(0.35)\end{array}$ & $\begin{array}{c}1.26 \\
(0.74)\end{array}$ & $\begin{array}{l}1.77^{* * *} \\
(0.57)\end{array}$ & $\begin{array}{c}0.34 \\
(0.31)\end{array}$ & $\begin{array}{l}-0.03 \\
(0.54)\end{array}$ \\
\hline U.S. Yield Gap & $\begin{array}{l}-4.18^{* *} \\
(1.81)\end{array}$ & $\begin{array}{l}-4.63^{* *} \\
(2.01)\end{array}$ & $\begin{array}{l}-0.12 \\
(0.39)\end{array}$ & $\begin{array}{c}-3.22^{* * *} \\
(1.08)\end{array}$ & $\begin{array}{l}-2.54^{*} \\
(1.32)\end{array}$ & $\begin{array}{c}-1.41^{* *} \\
(0.55)\end{array}$ & $\begin{array}{l}-2.70 \\
(2.21)\end{array}$ & $\begin{array}{l}-1.53 \\
(1.06)\end{array}$ & $\begin{array}{l}-1.50^{*} \\
(0.78)\end{array}$ & $\begin{array}{l}0.33 \\
(0.24)\end{array}$ & $\begin{array}{c}0.71 \\
(0.45)\end{array}$ & $\begin{array}{c}1.13^{* * *} \\
(0.40)\end{array}$ & $\begin{array}{l}-0.47 \\
(0.31)\end{array}$ & $\begin{array}{c}0.54 \\
(0.73)\end{array}$ \\
\hline Constant & $\begin{array}{c}0.60 \\
(6.12)\end{array}$ & $\begin{array}{l}14.94 \\
(9.04)\end{array}$ & $\begin{array}{l}8.06 * * * \\
(2.44)\end{array}$ & $\begin{array}{c}20.25 * * * \\
(5.12)\end{array}$ & $\begin{array}{c}17.13^{* * *} \\
(5.95)\end{array}$ & $\begin{array}{c}5.61 \\
(4.31)\end{array}$ & $\begin{array}{l}7.06 \\
(7.50)\end{array}$ & $\begin{array}{c}22.39^{* * *} \\
(8.00)\end{array}$ & $\begin{array}{c}29.65 * * * \\
(7.94)\end{array}$ & $\begin{array}{c}3.10 \\
(3.00)\end{array}$ & $\begin{array}{l}-1.19 \\
(6.56)\end{array}$ & $\begin{array}{c}-13.71^{* * *} \\
(4.33)\end{array}$ & $\begin{array}{c}1.41 \\
(3.00)\end{array}$ & $\begin{array}{c}6.95 \\
(7.45)\end{array}$ \\
\hline Observations & 175 & 170 & 176 & 178 & 164 & 154 & 181 & 123 & 121 & 115 & 106 & 96 & 96 & 130 \\
\hline Number of groups & 32 & 33 & 33 & 34 & 34 & 34 & 34 & 34 & 34 & 33 & 33 & 32 & 32 & 34 \\
\hline Country Fixed Effects & YES & YES & YES & YES & YES & YES & YES & YES & YES & YES & YES & YES & YES & YES \\
\hline
\end{tabular}


Table AIII.2

\begin{tabular}{|c|c|c|c|c|c|c|c|c|c|c|c|c|c|c|}
\hline & \multicolumn{14}{|c|}{ ital Inflows (Share of GD } \\
\hline \multirow[b]{3}{*}{ VARIABLES } & (1) & (2) & (3) & (4) & (5) & (6) & (7) & (8) & (9) & (10) & (11) & (12) & (13) & (14) \\
\hline & \multicolumn{7}{|c|}{ High Episodes } & \multicolumn{7}{|c|}{ Low Episodes } \\
\hline & Total & Private & FDI & Portfolio & $\begin{array}{c}\text { Portfolio } \\
\text { Debt }\end{array}$ & $\begin{array}{c}\text { Porfolio } \\
\text { Equity }\end{array}$ & Other & Total & Private & FDI & Portfolio & $\begin{array}{c}\begin{array}{c}\text { Portfolio } \\
\text { Debt }\end{array} \\
\end{array}$ & $\begin{array}{c}\text { Porfolio } \\
\text { Equity }\end{array}$ & Other \\
\hline Growth differential & $\begin{array}{c}0.53^{* * *} \\
(0.15)\end{array}$ & $\begin{array}{c}0.61^{* * *} \\
(0.09)\end{array}$ & $\begin{array}{l}-0.02 \\
(0.05)\end{array}$ & $\begin{array}{c}0.10 \\
(0.08)\end{array}$ & $\begin{array}{l}-0.03 \\
(0.08)\end{array}$ & $\begin{array}{l}0.04^{* *} \\
(0.02)\end{array}$ & $\begin{array}{l}0.20^{*} \\
(0.11)\end{array}$ & $\begin{array}{c}0.46^{* * *} \\
(0.15)\end{array}$ & $\begin{array}{l}0.51^{* *} \\
(0.21)\end{array}$ & $\begin{array}{c}0.09 \\
(0.12)\end{array}$ & $\begin{array}{c}0.04 \\
(0.06)\end{array}$ & $\begin{array}{c}0.05 \\
(0.08)\end{array}$ & $\begin{array}{c}-0.05^{* * *} \\
(0.02)\end{array}$ & $\begin{array}{c}0.22^{* * *} \\
(0.07)\end{array}$ \\
\hline Interest rate differential & $\begin{array}{c}0.19 \\
(0.27)\end{array}$ & $\begin{array}{c}-0.71 \\
(0.60)\end{array}$ & $\begin{array}{c}-0.54^{* *} \\
(0.23)\end{array}$ & $\begin{array}{c}-0.31 \\
(0.24)\end{array}$ & $\begin{array}{c}-0.49 * * * \\
(0.17)\end{array}$ & $\begin{array}{l}0.14^{* *} \\
(0.05)\end{array}$ & $\begin{array}{c}0.51^{* * *} \\
(0.16)\end{array}$ & $\begin{array}{l}-0.24 \\
(0.26)\end{array}$ & $\begin{array}{c}0.07 \\
(0.29)\end{array}$ & $\begin{array}{l}-0.26 \\
(0.27)\end{array}$ & $\begin{array}{c}-0.09 * * \\
(0.04)\end{array}$ & $\begin{array}{l}0.14^{*} \\
(0.07)\end{array}$ & $\begin{array}{c}0.04 \\
(0.04)\end{array}$ & $\begin{array}{l}-0.07 \\
(0.14)\end{array}$ \\
\hline Trade openness & $\begin{array}{c}0.23 * * * \\
(0.08)\end{array}$ & $\begin{array}{l}0.22^{* *} \\
(0.09)\end{array}$ & $\begin{array}{l}0.12^{* *} \\
(0.05)\end{array}$ & $\begin{array}{l}0.09 * * \\
(0.04)\end{array}$ & $\begin{array}{l}0.08 * * \\
(0.03)\end{array}$ & $\begin{array}{l}-0.00 \\
(0.00)\end{array}$ & $\begin{array}{c}0.31^{* * *} \\
(0.08)\end{array}$ & $\begin{array}{c}-0.17^{* *} \\
(0.07)\end{array}$ & $\begin{array}{l}-0.09^{*} \\
(0.04)\end{array}$ & $\begin{array}{l}-0.01 \\
(0.05)\end{array}$ & $\begin{array}{l}-0.00 \\
(0.02)\end{array}$ & $\begin{array}{c}0.02 \\
(0.02)\end{array}$ & $\begin{array}{c}0.01 \\
(0.01)\end{array}$ & $\begin{array}{c}-0.02 \\
(0.05)\end{array}$ \\
\hline Reserves & $\begin{array}{c}0.05 \\
(0.09)\end{array}$ & $\begin{array}{c}0.10 \\
(0.07)\end{array}$ & $\begin{array}{l}0.12^{* *} \\
(0.05)\end{array}$ & $\begin{array}{l}0.04 * * \\
(0.02)\end{array}$ & $\begin{array}{l}0.04^{*} \\
(0.02)\end{array}$ & $\begin{array}{c}0.00 \\
(0.00)\end{array}$ & $\begin{array}{l}-0.02 \\
(0.08)\end{array}$ & $\begin{array}{c}0.04 \\
(0.04)\end{array}$ & $\begin{array}{c}0.03 \\
(0.04)\end{array}$ & $\begin{array}{c}0.03 \\
(0.04)\end{array}$ & $\begin{array}{l}-0.00 \\
(0.00)\end{array}$ & $\begin{array}{l}-0.00 \\
(0.01)\end{array}$ & $\begin{array}{l}-0.00 \\
(0.00)\end{array}$ & $\begin{array}{c}0.00 \\
(0.02)\end{array}$ \\
\hline ER Regime & $\begin{array}{c}0.22 \\
(0.95)\end{array}$ & $\begin{array}{l}-1.10 \\
(0.83)\end{array}$ & $\begin{array}{c}0.79 \\
(0.59)\end{array}$ & $\begin{array}{c}-0.70^{* *} \\
(0.30)\end{array}$ & $\begin{array}{l}-0.46^{*} \\
(0.23)\end{array}$ & $\begin{array}{l}-0.03 \\
(0.07)\end{array}$ & $\begin{array}{c}0.87 \\
(0.66)\end{array}$ & $\begin{array}{l}-0.14 \\
(1.04)\end{array}$ & $\begin{array}{l}-0.53 \\
(0.53)\end{array}$ & $\begin{array}{c}0.39 \\
(0.59)\end{array}$ & $\begin{array}{l}-0.03 \\
(0.33)\end{array}$ & $\begin{array}{c}-0.61^{* *} \\
(0.29)\end{array}$ & $\begin{array}{l}-0.10 \\
(0.07)\end{array}$ & $\begin{array}{l}-0.49 \\
(0.54)\end{array}$ \\
\hline Institutional Quality & $\begin{array}{l}-1.07 \\
(8.81)\end{array}$ & $\begin{array}{l}-4.23 \\
(6.04)\end{array}$ & $\begin{array}{c}-10.78^{*} \\
(6.30)\end{array}$ & $\begin{array}{c}7.94^{* * *} \\
(2.38)\end{array}$ & $\begin{array}{l}4.16 \\
(2.99)\end{array}$ & $\begin{array}{l}-0.34 \\
(0.70)\end{array}$ & $\begin{array}{c}12.63 \\
(11.33)\end{array}$ & $\begin{array}{l}-13.38 \\
(8.36)\end{array}$ & $\begin{array}{l}-6.98^{* *} \\
(3.33)\end{array}$ & $\begin{array}{c}1.77 \\
(5.68)\end{array}$ & $\begin{array}{c}1.85 \\
(2.17)\end{array}$ & $\begin{array}{l}1.56 \\
(2.01)\end{array}$ & $\begin{array}{c}0.58 \\
(0.51)\end{array}$ & $\begin{array}{c}0.13 \\
(3.99)\end{array}$ \\
\hline Income per capita & $\begin{array}{c}0.00 \\
(0.00)\end{array}$ & $\begin{array}{c}0.00 \\
(0.00)\end{array}$ & $\begin{array}{l}-0.00 \\
(0.00)\end{array}$ & $\begin{array}{l}-0.00 \\
(0.00)\end{array}$ & $\begin{array}{l}-0.00 \\
(0.00)\end{array}$ & $\begin{array}{c}0.00 \\
(0.00)\end{array}$ & $\begin{array}{c}0.00 \\
(0.00)\end{array}$ & $\begin{array}{l}-0.00^{*} \\
(0.00)\end{array}$ & $\begin{array}{l}-0.00^{*} \\
(0.00)\end{array}$ & $\begin{array}{c}0.00 \\
(0.00)\end{array}$ & $\begin{array}{c}0.00 \\
(0.00)\end{array}$ & $\begin{array}{l}-0.00 \\
(0.00)\end{array}$ & $\begin{array}{l}-0.00 \\
(0.00)\end{array}$ & $\begin{array}{l}-0.00 \\
(0.00)\end{array}$ \\
\hline Capital account openness & $\begin{array}{l}-0.75 \\
(3.31)\end{array}$ & $\begin{array}{c}0.20 \\
(3.96)\end{array}$ & $\begin{array}{l}-1.22 \\
(1.76)\end{array}$ & $\begin{array}{l}-3.84 \\
(3.23)\end{array}$ & $\begin{array}{c}3.19 \\
(3.48)\end{array}$ & $\begin{array}{l}-0.05 \\
(0.41)\end{array}$ & $\begin{array}{c}0.20 \\
(4.72)\end{array}$ & $\begin{array}{c}1.84 \\
(4.11)\end{array}$ & $\begin{array}{c}10.32^{* * *} \\
(3.16)\end{array}$ & $\begin{array}{l}-4.85 \\
(3.25)\end{array}$ & $\begin{array}{l}-1.63 \\
(1.88)\end{array}$ & $\begin{array}{c}2.42 \\
(3.23)\end{array}$ & $\begin{array}{l}-0.83^{*} \\
(0.45)\end{array}$ & $\begin{array}{l}-1.22 \\
(2.97)\end{array}$ \\
\hline Financial Development & $\begin{array}{c}-57.56^{* * *} \\
(16.82)\end{array}$ & $\begin{array}{l}-32.89 \\
(19.28)\end{array}$ & $\begin{array}{l}-34.48 \\
(29.84)\end{array}$ & $\begin{array}{l}-12.82 \\
(10.04)\end{array}$ & $\begin{array}{c}-26.29^{* *} \\
(10.76)\end{array}$ & $\begin{array}{c}0.45 \\
(3.52)\end{array}$ & $\begin{array}{l}-45.76^{* *} \\
(19.47)\end{array}$ & $\begin{array}{c}-4.04 \\
(40.49)\end{array}$ & $\begin{array}{c}6.23 \\
(17.20)\end{array}$ & $\begin{array}{l}-21.66 \\
(24.86)\end{array}$ & $\begin{array}{c}5.19 \\
(5.76)\end{array}$ & $\begin{array}{c}2.65 \\
(4.16)\end{array}$ & $\begin{array}{l}-0.93 \\
(2.52)\end{array}$ & $\begin{array}{c}2.20 \\
(15.98)\end{array}$ \\
\hline Global risk aversion (log) & $\begin{array}{c}9.88 \\
(7.03)\end{array}$ & $\begin{array}{l}8.02 \\
(9.01)\end{array}$ & $\begin{array}{l}9.63^{* *} \\
(3.61)\end{array}$ & $\begin{array}{c}0.91 \\
(2.24)\end{array}$ & $\begin{array}{l}-1.25 \\
(2.31)\end{array}$ & $\begin{array}{c}0.17 \\
(0.27)\end{array}$ & $\begin{array}{c}3.03 \\
(4.98)\end{array}$ & $\begin{array}{c}0.98 \\
(2.48)\end{array}$ & $\begin{array}{c}6.87 \\
(5.86)\end{array}$ & $\begin{array}{c}6.74 \\
(4.01)\end{array}$ & $\begin{array}{l}-0.26 \\
(0.53)\end{array}$ & $\begin{array}{l}-0.01 \\
(0.99)\end{array}$ & $\begin{array}{l}-0.10 \\
(0.27)\end{array}$ & $\begin{array}{l}-1.87 \\
(1.18)\end{array}$ \\
\hline Commodity prices (growth) & $\begin{array}{l}-0.02 \\
(0.03)\end{array}$ & $\begin{array}{l}0.07^{*} \\
(0.04)\end{array}$ & $\begin{array}{c}0.01 \\
(0.02)\end{array}$ & $\begin{array}{c}0.05^{* * *} \\
(0.01)\end{array}$ & $\begin{array}{c}0.06 * * * \\
(0.01)\end{array}$ & $\begin{array}{c}-0.01 * * \\
(0.00)\end{array}$ & $\begin{array}{l}-0.04 \\
(0.04)\end{array}$ & $\begin{array}{l}-0.02 \\
(0.03)\end{array}$ & $\begin{array}{l}-0.02 \\
(0.03)\end{array}$ & $\begin{array}{l}-0.01 \\
(0.01)\end{array}$ & $\begin{array}{c}0.00 \\
(0.01)\end{array}$ & $\begin{array}{l}-0.00 \\
(0.01)\end{array}$ & $\begin{array}{c}0.00 \\
(0.00)\end{array}$ & $\begin{array}{c}-0.03^{* * *} \\
(0.01)\end{array}$ \\
\hline Global liquidity (growth) & $\begin{array}{c}0.46 \\
(0.32)\end{array}$ & $\begin{array}{c}0.38 \\
(0.36)\end{array}$ & $\begin{array}{l}0.29^{*} \\
(0.15)\end{array}$ & $\begin{array}{c}0.13 \\
(0.09)\end{array}$ & $\begin{array}{l}-0.09 \\
(0.08)\end{array}$ & $\begin{array}{c}0.01 \\
(0.01)\end{array}$ & $\begin{array}{c}0.21 \\
(0.26)\end{array}$ & $\begin{array}{c}0.25 \\
(0.19)\end{array}$ & $\begin{array}{c}0.58 \\
(0.37)\end{array}$ & $\begin{array}{c}0.10 \\
(0.09)\end{array}$ & $\begin{array}{c}0.04 \\
(0.03)\end{array}$ & $\begin{array}{c}0.04 \\
(0.06)\end{array}$ & $\begin{array}{c}0.01 \\
(0.01)\end{array}$ & $\begin{array}{c}0.02 \\
(0.10)\end{array}$ \\
\hline U.S. Corporate Spread & $\begin{array}{c}-8.17 * * * \\
(2.51)\end{array}$ & $\begin{array}{l}-5.49 * \\
(2.95)\end{array}$ & $\begin{array}{c}-3.66 * * \\
(1.53)\end{array}$ & $\begin{array}{c}-2.16 * * * \\
(0.74)\end{array}$ & $\begin{array}{c}-1.69 * * \\
(0.81)\end{array}$ & $\begin{array}{c}-0.75 * * * \\
(0.17)\end{array}$ & $\begin{array}{l}-3.91^{*} \\
(2.08)\end{array}$ & $\begin{array}{l}-3.04 \\
(2.52)\end{array}$ & $\begin{array}{l}-8.13 \\
(5.75)\end{array}$ & $\begin{array}{c}-4.68^{* *} \\
(2.10)\end{array}$ & $\begin{array}{c}0.02 \\
(0.31)\end{array}$ & $\begin{array}{l}-0.50 \\
(0.79)\end{array}$ & $\begin{array}{l}-0.07 \\
(0.15)\end{array}$ & $\begin{array}{c}2.64 * * * \\
(0.93)\end{array}$ \\
\hline U.S. Yield Gap & $\begin{array}{l}-5.52^{*} \\
(2.79)\end{array}$ & $\begin{array}{c}-6.17^{* * *} \\
(2.14)\end{array}$ & $\begin{array}{c}-5.02^{* *} \\
(1.87)\end{array}$ & $\begin{array}{c}-1.86 * * * \\
(0.54)\end{array}$ & $\begin{array}{c}-1.62^{* *} \\
(0.67)\end{array}$ & $\begin{array}{l}-0.03 \\
(0.15)\end{array}$ & $\begin{array}{c}0.60 \\
(1.58)\end{array}$ & $\begin{array}{l}-1.06 \\
(2.06)\end{array}$ & $\begin{array}{l}-6.43^{*} \\
(3.64)\end{array}$ & $\begin{array}{l}-2.62^{*} \\
(1.39)\end{array}$ & $\begin{array}{l}-0.57 \\
(0.59)\end{array}$ & $\begin{array}{l}-0.12 \\
(0.83)\end{array}$ & $\begin{array}{c}0.18 \\
(0.17)\end{array}$ & $\begin{array}{c}2.26^{* * * *} \\
(0.75)\end{array}$ \\
\hline Constant & $\begin{array}{c}13.65 \\
(18.93)\end{array}$ & $\begin{array}{c}7.61 \\
(19.25)\end{array}$ & $\begin{array}{l}-7.62 \\
(8.16)\end{array}$ & $\begin{array}{c}16.86^{* *} \\
(7.37)\end{array}$ & $\begin{array}{c}27.40^{* * *} \\
(7.78)\end{array}$ & $\begin{array}{c}1.71 \\
(1.58)\end{array}$ & $\begin{array}{c}-2.44 \\
(17.96)\end{array}$ & $\begin{array}{c}17.35 \\
(17.44)\end{array}$ & $\begin{array}{c}7.40 \\
(13.66)\end{array}$ & $\begin{array}{c}6.41 \\
(9.01)\end{array}$ & $\begin{array}{l}-1.48 \\
(3.33)\end{array}$ & $\begin{array}{l}-2.88 \\
(4.58)\end{array}$ & $\begin{array}{c}0.46 \\
(1.52)\end{array}$ & $\begin{array}{l}-6.55 \\
(7.38)\end{array}$ \\
\hline Observations & 182 & 176 & 171 & 181 & 172 & 207 & 160 & 102 & 104 & 102 & 87 & 75 & 78 & 108 \\
\hline Number of groups & 32 & 33 & 33 & 34 & 33 & 33 & 33 & 33 & 34 & 33 & 30 & 28 & 26 & 33 \\
\hline Country Fixed Effects & YES & YES & YES & YES & YES & YES & YES & YES & YES & YES & YES & YES & YES & YES \\
\hline
\end{tabular}

Standard errors in parentheses
$* * *$
$0<0.01, * * p<0.05, * p<0.1$

Table AIII.3

\begin{tabular}{|c|c|c|c|c|c|c|c|c|c|c|c|c|c|c|}
\hline & \\
\hline \multirow[b]{3}{*}{ VARIABLES } & (1) & (2) & (3) & (4) & (5) & (6) & (7) & (8) & (9) & (10) & (11) & (12) & (13) & (14) \\
\hline & \multicolumn{7}{|c|}{ High Episodes } & \multicolumn{7}{|c|}{ Low Episodes } \\
\hline & Total & Private & FDI & Portfolio & $\begin{array}{c}\text { Portfolio } \\
\text { Debt }\end{array}$ & $\begin{array}{c}\text { Porfolio } \\
\text { Equity }\end{array}$ & Other & Total & Private & FDI & Portfolio & $\begin{array}{c}\text { Portfolio } \\
\text { Debt }\end{array}$ & $\begin{array}{c}\text { Porfolio } \\
\text { Equity }\end{array}$ & Other \\
\hline Growth differential & $\begin{array}{l}0.18^{* *} \\
(0.08)\end{array}$ & $\begin{array}{c}0.06 \\
(0.09)\end{array}$ & $\begin{array}{c}0.04 \\
(0.04)\end{array}$ & $\begin{array}{l}0.10^{* *} \\
(0.04)\end{array}$ & $\begin{array}{l}0.09 * * \\
(0.04)\end{array}$ & $\begin{array}{l}-0.00 \\
(0.01)\end{array}$ & $\begin{array}{c}0.02 \\
(0.12)\end{array}$ & $\begin{array}{l}-0.08 \\
(0.10)\end{array}$ & $\begin{array}{l}-0.09 \\
(0.14)\end{array}$ & $\begin{array}{l}-0.02 \\
(0.06)\end{array}$ & $\begin{array}{c}0.24^{* *} \\
(0.09)\end{array}$ & $\begin{array}{c}0.15^{* * *} \\
(0.05)\end{array}$ & $\begin{array}{c}0.24 \\
(0.15)\end{array}$ & $\begin{array}{c}0.03 \\
(0.07)\end{array}$ \\
\hline Interest rate differential & $\begin{array}{c}-0.49^{* * *} \\
(0.16)\end{array}$ & $\begin{array}{c}-0.72 * * * \\
(0.22)\end{array}$ & $\begin{array}{c}-0.45^{* *} \\
(0.21)\end{array}$ & $\begin{array}{c}0.07 \\
(0.10)\end{array}$ & $\begin{array}{c}0.25 \\
(0.15)\end{array}$ & $\begin{array}{l}-0.08^{*} \\
(0.05)\end{array}$ & $\begin{array}{c}-0.24^{* *} \\
(0.10)\end{array}$ & $\begin{array}{c}0.01 \\
(0.07)\end{array}$ & $\begin{array}{l}-0.06 \\
(0.12)\end{array}$ & $\begin{array}{l}-0.55 \\
(0.41)\end{array}$ & $\begin{array}{c}0.08 \\
(0.11)\end{array}$ & $\begin{array}{l}0.10^{*} \\
(0.05)\end{array}$ & $\begin{array}{l}-0.08 \\
(0.16)\end{array}$ & $\begin{array}{c}0.11 \\
(0.08)\end{array}$ \\
\hline Trade openness & $\begin{array}{c}0.27^{* * *} \\
(0.04)\end{array}$ & $\begin{array}{c}0.16^{* * *} \\
(0.05)\end{array}$ & $\begin{array}{l}0.09^{* *} \\
(0.04)\end{array}$ & $\begin{array}{c}0.05 \\
(0.03)\end{array}$ & $\begin{array}{c}0.01 \\
(0.03)\end{array}$ & $\begin{array}{l}-0.01 \\
(0.00)\end{array}$ & $\begin{array}{c}0.22^{* * * *} \\
(0.04)\end{array}$ & $\begin{array}{l}-0.10^{*} \\
(0.05)\end{array}$ & $\begin{array}{l}-0.04 \\
(0.04)\end{array}$ & $\begin{array}{l}-0.03 \\
(0.03)\end{array}$ & $\begin{array}{c}0.04 \\
(0.02)\end{array}$ & $\begin{array}{c}0.04 \\
(0.02)\end{array}$ & $\begin{array}{l}-0.10^{*} \\
(0.05)\end{array}$ & $\begin{array}{c}0.01 \\
(0.04)\end{array}$ \\
\hline Reserves & $\begin{array}{c}0.01 \\
(0.05)\end{array}$ & $\begin{array}{c}0.02 \\
(0.06)\end{array}$ & $\begin{array}{c}0.07 \\
(0.05)\end{array}$ & $\begin{array}{c}0.01 \\
(0.02)\end{array}$ & $\begin{array}{c}0.01 \\
(0.01)\end{array}$ & $\begin{array}{l}0.01^{* *} \\
(0.00)\end{array}$ & $\begin{array}{c}-0.11^{* *} \\
(0.04)\end{array}$ & $\begin{array}{l}0.06^{* *} \\
(0.02)\end{array}$ & $\begin{array}{c}0.04 \\
(0.02)\end{array}$ & $\begin{array}{l}0.06^{*} \\
(0.03)\end{array}$ & $\begin{array}{c}0.01 \\
(0.01)\end{array}$ & $\begin{array}{l}-0.02 \\
(0.01)\end{array}$ & $\begin{array}{l}-0.02 \\
(0.02)\end{array}$ & $\begin{array}{l}0.01 \\
(0.01)\end{array}$ \\
\hline ER Regime & $\begin{array}{c}2.02^{* * *} \\
(0.66)\end{array}$ & $\begin{array}{c}0.71 \\
(0.83)\end{array}$ & $\begin{array}{l}-0.91 \\
(0.57)\end{array}$ & $\begin{array}{c}0.45 \\
(0.43)\end{array}$ & $\begin{array}{c}0.72 \\
(0.43)\end{array}$ & $\begin{array}{c}0.01 \\
(0.10)\end{array}$ & $\begin{array}{c}1.49 \\
(0.92)\end{array}$ & $\begin{array}{l}-0.25 \\
(0.33)\end{array}$ & $\begin{array}{l}-0.17 \\
(0.24)\end{array}$ & $\begin{array}{l}-0.20 \\
(0.47)\end{array}$ & $\begin{array}{c}-1.11^{* * *} \\
(0.21)\end{array}$ & $\begin{array}{c}-1.47^{* * *} \\
(0.45)\end{array}$ & $\begin{array}{c}0.21 \\
(0.25)\end{array}$ & $\begin{array}{l}-0.07 \\
(0.27)\end{array}$ \\
\hline Institutional Quality & $\begin{array}{c}1.46 \\
(10.30)\end{array}$ & $\begin{array}{l}-4.45 \\
(8.34)\end{array}$ & $\begin{array}{l}-5.61 \\
(6.21)\end{array}$ & $\begin{array}{c}6.59 * * * \\
(2.07)\end{array}$ & $\begin{array}{l}2.82 \\
(1.93)\end{array}$ & $\begin{array}{l}-1.42^{*} \\
(0.71)\end{array}$ & $\begin{array}{c}25.02^{* *} \\
(9.17)\end{array}$ & $\begin{array}{l}-1.07 \\
(4.14)\end{array}$ & $\begin{array}{c}0.08 \\
(2.71)\end{array}$ & $\begin{array}{l}-2.39 \\
(2.84)\end{array}$ & $\begin{array}{c}2.33 \\
(2.01)\end{array}$ & $\begin{array}{l}-0.92 \\
(1.76)\end{array}$ & $\begin{array}{l}-4.16 \\
(2.82)\end{array}$ & $\begin{array}{l}-0.77 \\
(2.11)\end{array}$ \\
\hline Income per capita & $\begin{array}{l}-0.00 \\
(0.00)\end{array}$ & $\begin{array}{l}-0.00 \\
(0.00)\end{array}$ & $\begin{array}{c}0.00 \\
(0.00)\end{array}$ & $\begin{array}{l}0.00^{* *} \\
(0.00)\end{array}$ & $\begin{array}{c}0.00 \\
(0.00)\end{array}$ & $\begin{array}{c}0.00 \\
(0.00)\end{array}$ & $\begin{array}{c}0.00 \\
(0.00)\end{array}$ & $\begin{array}{l}-0.00 \\
(0.00)\end{array}$ & $\begin{array}{l}-0.00 \\
(0.00)\end{array}$ & $\begin{array}{c}0.00 \\
(0.00)\end{array}$ & $\begin{array}{c}0.00 \\
(0.00)\end{array}$ & $\begin{array}{l}-0.00 \\
(0.00)\end{array}$ & $\begin{array}{c}0.00 \\
(0.00)\end{array}$ & $\begin{array}{l}0.00^{* *} \\
(0.00)\end{array}$ \\
\hline Capital account openness & $\begin{array}{l}4.82^{*} \\
(2.43)\end{array}$ & $\begin{array}{c}8.15^{* * *} \\
(2.83)\end{array}$ & $\begin{array}{l}-5.47^{*} \\
(3.01)\end{array}$ & $\begin{array}{l}2.34 * * \\
(1.13)\end{array}$ & $\begin{array}{c}0.43 \\
(1.10)\end{array}$ & $\begin{array}{c}0.19 \\
(0.49)\end{array}$ & $\begin{array}{l}1.30 \\
(3.36)\end{array}$ & $\begin{array}{l}-0.95 \\
(2.09)\end{array}$ & $\begin{array}{l}2.10 \\
(1.96)\end{array}$ & $\begin{array}{l}-0.71 \\
(2.62)\end{array}$ & $\begin{array}{l}-1.48 \\
(1.53)\end{array}$ & $\begin{array}{l}-4.93 \\
(2.98)\end{array}$ & $\begin{array}{l}-7.40^{*} \\
(4.11)\end{array}$ & $\begin{array}{c}1.51 \\
(1.98)\end{array}$ \\
\hline Financial Development & $\begin{array}{c}-81.90^{* * *} \\
(19.77)\end{array}$ & $\begin{array}{c}-65.74 * * * \\
(16.22)\end{array}$ & $\begin{array}{l}-21.55 \\
(19.62)\end{array}$ & $\begin{array}{c}-44.83^{* * *} \\
(9.04)\end{array}$ & $\begin{array}{c}-48.20 * * * \\
(12.90)\end{array}$ & $\begin{array}{c}-6.98^{* * *} \\
(2.25)\end{array}$ & $\begin{array}{l}-42.74^{*} \\
(21.44)\end{array}$ & $\begin{array}{c}3.39 \\
(16.91)\end{array}$ & $\begin{array}{c}10.15 \\
(21.19)\end{array}$ & $\begin{array}{l}-21.52 \\
(17.72)\end{array}$ & $\begin{array}{c}-0.35 \\
(10.90)\end{array}$ & $\begin{array}{l}7.95 \\
(5.78)\end{array}$ & $\begin{array}{l}58.70^{* *} \\
(26.89)\end{array}$ & $\begin{array}{c}2.72 \\
(6.24)\end{array}$ \\
\hline Global risk aversion (log) & $\begin{array}{l}4.31 \\
(3.97)\end{array}$ & $\begin{array}{c}4.63 \\
(4.07)\end{array}$ & $\begin{array}{l}9.74^{* *} \\
(4.39)\end{array}$ & $\begin{array}{c}0.57 \\
(1.29)\end{array}$ & $\begin{array}{l}-0.26 \\
(1.06)\end{array}$ & $\begin{array}{c}0.37 \\
(0.26)\end{array}$ & $\begin{array}{l}-1.42 \\
(2.06)\end{array}$ & $\begin{array}{l}3.62 \\
(2.55)\end{array}$ & $\begin{array}{l}3.97 \\
(2.85)\end{array}$ & $\begin{array}{l}5.46 \\
(3.69)\end{array}$ & $\begin{array}{c}-2.30^{* * *} \\
(0.46)\end{array}$ & $\begin{array}{c}-2.77^{* * *} \\
(0.54)\end{array}$ & $\begin{array}{l}-1.98^{*} \\
(1.06)\end{array}$ & $\begin{array}{c}2.03 \\
(1.35)\end{array}$ \\
\hline Commodity prices (growth) & $\begin{array}{l}-0.00 \\
(0.03)\end{array}$ & $\begin{array}{c}0.00 \\
(0.02)\end{array}$ & $\begin{array}{c}0.02 \\
(0.02)\end{array}$ & $\begin{array}{c}-0.02^{* *} \\
(0.01)\end{array}$ & $\begin{array}{l}-0.00 \\
(0.01)\end{array}$ & $\begin{array}{c}-0.01^{* * *} \\
(0.00)\end{array}$ & $\begin{array}{c}0.01 \\
(0.02)\end{array}$ & $\begin{array}{c}0.00 \\
(0.01)\end{array}$ & $\begin{array}{l}-0.01 \\
(0.01)\end{array}$ & $\begin{array}{l}-0.01 \\
(0.01)\end{array}$ & $\begin{array}{l}-0.00 \\
(0.01)\end{array}$ & $\begin{array}{c}0.03^{* * *} \\
(0.00)\end{array}$ & $\begin{array}{c}0.01 \\
(0.02)\end{array}$ & $\begin{array}{l}-0.01 \\
(0.01)\end{array}$ \\
\hline Global liquidity (growth) & $\begin{array}{c}0.13 \\
(0.22)\end{array}$ & $\begin{array}{c}0.05 \\
(0.18)\end{array}$ & $\begin{array}{l}0.30^{*} \\
(0.16)\end{array}$ & $\begin{array}{l}0.15^{*} \\
(0.08)\end{array}$ & $\begin{array}{l}0.10^{*} \\
(0.05)\end{array}$ & $\begin{array}{c}0.03^{* * *} \\
(0.01)\end{array}$ & $\begin{array}{l}-0.19^{*} \\
(0.11)\end{array}$ & $\begin{array}{c}0.19 \\
(0.16)\end{array}$ & $\begin{array}{c}0.15 \\
(0.16)\end{array}$ & $\begin{array}{l}-0.04 \\
(0.12)\end{array}$ & $\begin{array}{c}0.05 \\
(0.04)\end{array}$ & $\begin{array}{c}0.05 \\
(0.05)\end{array}$ & $\begin{array}{c}-0.17^{* *} \\
(0.08)\end{array}$ & $\begin{array}{c}0.01 \\
(0.06)\end{array}$ \\
\hline U.S. Corporate Spread & $\begin{array}{c}-4.55^{* * *} \\
(1.46)\end{array}$ & $\begin{array}{c}-4.57^{* * *} \\
(1.32)\end{array}$ & $\begin{array}{c}-3.54^{* *} \\
(1.56)\end{array}$ & $\begin{array}{c}-1.63^{* * *} \\
(0.51)\end{array}$ & $\begin{array}{c}-1.43 * * * \\
(0.36)\end{array}$ & $\begin{array}{c}-0.68^{* * *} \\
(0.10)\end{array}$ & $\begin{array}{l}-1.51^{*} \\
(0.81)\end{array}$ & $\begin{array}{l}-1.92 \\
(1.99)\end{array}$ & $\begin{array}{l}-2.13 \\
(2.22)\end{array}$ & $\begin{array}{l}-4.24 \\
(2.99)\end{array}$ & $\begin{array}{l}1.76 * * \\
(0.77)\end{array}$ & $\begin{array}{c}2.20^{* * *} \\
(0.54)\end{array}$ & $\begin{array}{l}-0.27 \\
(0.55)\end{array}$ & $\begin{array}{l}-1.26 \\
(1.05)\end{array}$ \\
\hline U.S. Yield Gap & $\begin{array}{l}-2.71 \\
(2.65)\end{array}$ & $\begin{array}{l}-1.62 \\
(2.15)\end{array}$ & $\begin{array}{c}-4.98 * * \\
(2.19)\end{array}$ & $\begin{array}{l}-1.20^{*} \\
(0.67)\end{array}$ & $\begin{array}{c}-1.49 * * * \\
(0.49)\end{array}$ & $\begin{array}{c}0.20 \\
(0.19)\end{array}$ & $\begin{array}{l}1.69 \\
(1.23)\end{array}$ & $\begin{array}{l}-1.50 \\
(1.08)\end{array}$ & $\begin{array}{l}-0.61 \\
(1.36)\end{array}$ & $\begin{array}{l}-1.27 \\
(1.10)\end{array}$ & $\begin{array}{c}0.43 \\
(0.92)\end{array}$ & $\begin{array}{l}-0.04 \\
(0.57)\end{array}$ & $\begin{array}{l}0.09 \\
(0.69)\end{array}$ & $\begin{array}{l}-0.32 \\
(0.54)\end{array}$ \\
\hline Constant & $\begin{array}{c}23.74^{* * *} \\
(8.03)\end{array}$ & $\begin{array}{c}25.79 \\
(15.43)\end{array}$ & $\begin{array}{l}-3.88 \\
(6.97)\end{array}$ & $\begin{array}{c}14.10^{* * *} \\
(4.49)\end{array}$ & $\begin{array}{c}20.52^{* * *} \\
(3.75)\end{array}$ & $\begin{array}{l}3.29^{*} \\
(1.73)\end{array}$ & $\begin{array}{c}21.45^{* *} \\
(9.77)\end{array}$ & $\begin{array}{l}-6.23 \\
(9.05)\end{array}$ & $\begin{array}{l}-15.16 \\
(9.70)\end{array}$ & $\begin{array}{l}-2.78 \\
(5.44)\end{array}$ & $\begin{array}{l}-1.90 \\
(4.46)\end{array}$ & $\begin{array}{l}4.47 \\
(6.37)\end{array}$ & $\begin{array}{l}-9.01 \\
(7.11)\end{array}$ & $\begin{array}{c}-13.64 * * \\
(6.13)\end{array}$ \\
\hline Observations & 173 & 170 & 173 & 162 & 174 & 197 & 175 & 120 & 124 & 86 & 80 & 73 & 58 & 124 \\
\hline Number of groups & 34 & 34 & 34 & 33 & 33 & 33 & 34 & 34 & 34 & 29 & 31 & 28 & 25 & 33 \\
\hline Country Fixed Effects & YES & YES & YES & YES & YES & YES & YES & YES & YES & YES & YES & YES & YES & YES \\
\hline
\end{tabular}

${ }^{* * *} p<0.01,{ }^{* *} p<0.05,{ }^{*} p<0.1$ 